\title{
Lectura crítica de los catecismos de Astete y Ripalda
}

\author{
PRIMERA PARTE
}

\author{
LECTURA CRÍTICA DEL CATECISMO DE ASTETE
}

\section{Introducción}

El conocimiento de unos textos de catecismo que tienen a sus espaldas casi cuatro siglos debería tener el carácter de redescubrimiento ${ }^{1}$ si no hubiera concurrido la circunstancia de haber permanecido en vigor hasta hace unos años, como ha ocurrido con el texto del P. Gaspar Astete y su gemelo elaborado por el P. Jerónimo de Ripalda.

El hecho de haber continuado usando dichos textos durante algo más de tres siglos y medio podría ser considerado como una muestra inequívoca de la intrínseca calidad de sus afirmaciones y enseñanzas, así como del aprecio mantenido una generación tras otra. Pero no sin fundamento puede ser considerado como un abandono de la Iglesia española a la inercia de la costumbre, dejando que edición tras edición fuera presentado el mismo contenido de la fe, sin hacer un esfuerzo de actualizar su formulación o adaptarlo a las nuevas exigencias de la vida de la Iglesia o las condiciones ambientales ${ }^{2}$.

1. Este tono de redescubrimiento rodea la aparición del catecismo de Bartolomé de CARranza, Comentarios sobre el Catechismo christiano, edición preparada por su historiador J. I. TEllecheA. Madrid, 1972 (Ed. BAC).

Otro tanto puede decirse de la obra de J.R. Guerrero, Catecismos espantoles del siglo XVI, (Madrid, 1969), consagrada al estudio de la obra catequética de Constantino Ponce de la Fuente.

2. Entre los hechos más notables de la vida de lá Iglesia se pueden destacar el jansenismo, el racionalismo, la declaración de la Inmaculada Concepción, el Vaticano I y la infalibilidad, la apertura a la hermenéutica bíblica, el modernismo, la creación de un pensamiento social cristiano, la declaración de la Asunción de María. Tan sólo algunos de estos sucesos tuvieron acogida en las páginas de los catecismos utilizados.

Entre las circunstancias ambientales que modificaron la estrutura de la sociedad y la configuración de la vida humana cabría destacar la Ilustración, la revolución industrial, la aparición del socialismo y del comunismo, las dos guerras mundiales y la progresiva incorporación de todos los 
Durante tan prolongado lapso de tiempo hicieron su aparición algunos otros catecismos, fruto de intentos varios de acomodación a las nuevas condiciones de vida ${ }^{3}$, pero ninguno de ellos tuvo fuerza y aceptación suficiente para desbancar de una manera definitiva a los textos de Astete y Ripalda, que continuaron nutriendo la fe tradicional del pueblo cristiano, si prescindimos de las formas de piedad, sermones, etc..., donde estaba presente una carga de contenido teológico muy diverso.

La pervivencia de ambos textos tuvo una expresión geográfica, con la adopción oficial $u$ oficiosa de uno $u$ otro texto en diversas diócesis. $Y$ aunque no toda la geografía nacional estaba cubierta por ambos catecismos, una gran parte era tributaria de las formulaciones en ellos contenidas ${ }^{4}$.

La publicación entre los años 1957-1961 del denominado «Catecismo Nacional», texto refrendado y aprobado por los obispos españoles a través de la Comisión Espiscopal de Enseñanza y adoptado como texto único para toda la nación, derogó las disposiciones anteriores respecto a la adaptación oficial en cada diócesis de otros textos. A partir de aquel momento se inició el despegue en el campo catequético respecto a la tradición secular de adoptar textos del pasado. Los catecismos entonces aparecidos eran en gran medida deudores de sus inmediatos predecesores. Pero los primeros pasos estaban dados. Las etapas más recientes son lo suficientemente conocidas como para poder omitir aquí una descripción detallada. Aparte ha surgido un movimiento creativo de imaginación y acomodación a las nuevas necesidades que ha querido ser frenado con nostálgicas regresiones al pasado, volviendo su mirada a ambos textos sin reparar que el proceso de constantes ediciones y actualizaciones es la prueba irrefutable de una tradición "viva», cuyo propósito ha sido el de actualizar en cada circunstancia los instrumentos de educación de la fe para res-

estamentos de la sociedad a la vida pública. Tampoco estos acontecimientos encontraron mucho eco en los catecismos.

3. Entre los principales catecismos españoles posteriores a Astete y Ripalda, cabría destacar, en el siglo XVII los de Pedro de Tapia, Pedro Vives y Juan Eusebio Nieremberg, redactado este último con los materiales aportados por Jerónimo López. En el siglo XVIII coexisten algunos textos procedentes del extranjero (los de Belarmino, Canisio, Fleury) con otros confeccionados entonces (los de José Pintón y Pedro de Calatayud), además de seguir usando los anteriores. En el siglo XIX destacan en la producción nacional los nombres de Santiago José García Mazo, Antonio María Claret, Cayetano Ramo, Enrique Ossó y Ángel María Arcos. Junto a ellos, procedentes del extranjero, habría que añadir los de Deharbe y Spirago.

Puede consultarse el artículo de Juan María SolÁ, El catecismo único en España, en "Razón y Fe», 15 (1906), pp. 306-323; 16 (1906), p. 58-71; Id. p. 469-479; y 17 (1907), p. 202-211.

4. El texto de Astete era usado en 23 diócesis: Mondoñedo, Santiago, Tuy, Orense, Oviedo, Astorga, León, Santander, Vitoria, Burgos, Pamplona, Calahorra, Osma, Zaragoza, Palencia, Valladolid, Zamora, Segovia, Ciudad Rodrigo, Salamanca, Ávila, Madrid y Cádiz. El de Ripalda estaba implantado en 17: Siguenza, Madrid, Cuenca, Toledo, Coria, Plasencia, Orihuela, Cartagena, Almería, Guadix, Granada, Málaga, Córdoba, Cádiz, Sevilla, Tenerife y Canarias. (Ver Crónica oficial del primer Congreso Catequístico nacional Español, Valladolid, 1914, tomo I, pp. 327-329). 
ponder a las más perentorias necesidades. Semejante proceso de gestación obliga a rechazar una tradición "muerta», "fosilizada».

El primer intento de regresión ha sido llevado a cabo por la Editorial Magisterio Español ${ }^{5}$. En la introducción se hace constar que:

«Nuestra intención, al hacer esta reedición, no es en ninguna forma la de que pueda servir como libro de enseñanza de la Doctrina Cristiana; pues, para ello ha editado la Comisión Episcopal de Enseñanza el Texto Nacional y últimamente el Catecismo Escolar. Nos guía el deseo, frecuentemente expresado por muchas personas, de ponerlo en manos de aquellos que, en sus años de infancia, hubieron de estudiarlo como libro de texto, así como de muchos estudiosos que desean tenerlo como libro de consulta para sus estudios de las obras maestras de la literatura religiosa.

En todo momento y al pie de página, se han puesto las notas correspondientes con todas las variaciones que en materia de disciplina o legislación han cambiado desde que se escribió el original hasta nuestros días, respetando en el cuerpo de la obra el original que, en su día, escribió el P. Astete».

Aunque no hay nada que oponer al primer párrafo reproducido acerca de la intención de la editorial, el segundo párrafo deja mucho que desear, pues con la ignorancia de quien afirma lo que desconoce, no sólo no reproduce «el original que, en su día, escribió el P. Astete», sino que dicha edición constituye un plagio de la adaptación que sobre la obra de Astete habían realizado varios autores y que culminó en las ediciones que publicara Daniel Llorente ${ }^{6}$.

El segundo intento ha cristalizado en la edición que a cargo del P. Arturo Alonso Lobo, O.P. ha visto la luz en Salamanca ${ }^{7}$. Tal edición se encuentra justificada de la siguiente forma:

Es posible que algunos tachen de ingenuidad el recuerdo de aquellos $\mathrm{Ca}-$ tecismos clásicos, como el «Astete» y el «Ripalda», que formaron en el pasado a tantas generaciones de cristianos.

5. Catecismo de la Doctrina Cristiana, P. Astete. Editorial Magisterio Español, S.A., Madrid, 1969. «Colección F».

6. Publicadas en Valladolid, Casa Martín, entre los años 1913 y 1957. En los años 1955 y 1956 aparecieron dos ediciones que figuran indistintamente como la $24 .^{a}$, aunque ésta fue publicada en 1954.

7. Catecismo de la Doctrina Cristiana escrito por el P. Gaspar Astere, S.J. Novísima edición. Salamanca, 1977.

«Han aparecido otras ediciones del mismo en Salamanca, 1978 (2. a ed.), Id. 1978, (3. ${ }^{\text {a }}$ ed. $)$ e Id. 1979 ( $4 .^{\mathrm{a}}$ ed.). Tan sólo en esta última dice: «En ella reproducimos el texto clásico (no digo «crítico») del P. Astete...». Lo cierto, como se verá a lo largo del presente trabajo, es quẹ no reproduce el texto "clásico» de Astete, sino otro corregido, añadido y desfigurado.

Además se han publicado: Catecismo de la doctrina cristiana. Texto del P. Astete. Actualizado por un grupo de sacerdotes y catequistas de la diócesis de Vitoria. Vitoria, 1977, y Catecismo de Ya doctrina cristiana. Kristau-Ikas dibea, Pamplona, 1979, texto bilingüe, en su versión castellana sobre el texto de Pamplona, 1933, y en la versión vasca șobre el de Pamplona, 1955. 
Sí, ya sé que los pedagogos modernos han levantado su voz contra el método memorista; pero lo que en la práctica consiguieron fue hacernos caer en el extremo opuesto de un conceptualismo ininteligible para los niños e inútil para los adultos. Actualmente los niños no entienden mejor los nuevos Catecismos y no se les urge la necesidad de aprenderlos de memoria; cuando lleguen a la mayoría de edad, caerán en el ateísmo - con todas sus consecuencias - ante la imposibilidad de querer y practicar lo que desconocen.

Dios ha querido que en el niño lo primero que se desarrolle sea la memoria; al correr del tiempo, irá la inteligencia rumiando y asimilando aquellas materias primas que se acumularon en ella. Por eso nuestros antepasados - que no tendrían que envidiar el celo de los actuales pastoralistas- procuraron sintetizar y resumir el dogma y la moral de nuestra religión católica en breves Catecismos, para que de niños los aprendiésemos de memoria y los entendiésemos según la capacidad receptiva de entonces; después, conforme iban pasando los años, era posible echar mano del caudal encerrado en el archivo de la memoria - que es una muy noble potencia del alma - para desentrañar su contenido y tratar de convertirlo en base y fundamento de nuestra vida cristiana.

Por este motivo, editamos a continuación uno de los tratados de teología más completos y sencillos a la vez que se escribieron para catequizar a los bautizados. Y lo hacemos con absoluto desinterés económico, pensando únicamente en el bien espiritual de nuestros niños, jóvenes y adultos, los cuales necesitan y desean conocer y vivir al menos el núcleo fundamental del credo religioso católico».

Fr. Arturo Alonso Lobo, O.P. Salamanca, 1 de mayo de 1977.

Una nota añadida al pie del prólogo aquí reproducido precisa como en el caso de la edición del Magisterio Español:

«Reproducimos el texto clásico del «Catecismo del P. Astete». Pero fue preciso introducir en él algunas modificaciones, sobre todo en materia de derecho positivo, para acomodar esta novísima edicion a las disposiciones actuales de la Iglesia».

Un intento semejante de reedición y puesta en circulación del catecismo de Ripalda ha cuajado en Granada, en 1979, a manos de Alberto Gómez Matarín, quien presenta elogiosamente la nueva edición ensalzando los valores de integridad, concisión y exactitud del catecismo.

Incide en el mismo error de óptica que les ha ocurrido a los editores de Astete al indicar:

«Reproducimos en esta edición el texto clásico del Catecismo del P. Jerónimo Ripalda, que ya resulta difícil de adquirir, y que muchos buscan con avidez.

Sólo se han modificado en él algunas preguntas para adaptarlas a las nuevas disposiciones de la Iglesia. 
Dichas modificaciones van señaladas al margen de cada una para conservar la mayor fidelidad».

Como ambos textos de Astete reconocen que, prescindiendo de adiciones y acomodaciones recientes, pretenden remontarse al texto original de Astete, es preciso hacer una clarificación en dicho catecismo con sentido crítico para restituir a Astete lo que le corresponde, pero para comprobar también que el texto ha llegado hasta nosotros como fruto de numerosas y notables adiciones. Las mismas afirmaciones tienen plena validez para el catecismo de Ripalda.

Una vez establecido esto, remitir a cualquiera de los textos obliga a hacer otras ediciones distintas de las que están en circulación, así como a no remitir indiscriminadamente a las autoridades de los padres Gaspar Astete y Jerónimo de Ripalda.

El presente estudio puede contribuir a arrojar luz sobre unos textos de catecismo que han sido notablemente alterados. Los originales, desprovistos de todo el ropaje envolvente, son menos perfectos y bastante distintos de lo que pretenden sus admiradores.

Centraremos nuestra visión en primer lugar en Astete y sus correctores, para hacer después lo propio con Ripalda y los suyos. Con ello estaremos en condiciones de asomarnos con sentido crítico a los respectivos textos.

\section{GASPAR ASTETE}

Gaspar Astete nació en Salamanca en 1537. Entró a formar parte de la Compañía de Jesús en 1555, haciendo la profesión de los cuatro votos en 1571. Fue confesor y predicador, rector de los colegios de Burgos y Villimar. De él dice el P. Rodeles en su obra La compañía de Jesús Catequista que poseía dotes singulares para dirigir y cultivar a la juventud en virtudes y letras. Murió en Burgos el 30 de agosto de $1601^{8}$. Se halla enterrado en medio de la sacristía de la iglesia de San Lorenzo el Real de Burgos debajo de la mesa central. Hasta el 1900 se veía el sepulcro, pero ese año poco más o menos fue cubierto al entarimar dicha sacristía. Enseñó humanidades y filosofía en la Universidad de Salamanca y seminario de Burgos, dirigiendo el gobierno de algunos colegios y del noviciado ${ }^{9}$.

Entre sus obras cabe contar con El modo de rezar el Rosario, Salmos y oraciones (Burgos, 1593), Del gobierno de la familia (Madrid, 1597), Del esta-

8. D. Llorente, Tratado elemental de Pedagogía Catequística, $10 .^{\mathrm{a}}$ ed. Valladolid, 1965 , p. 529.

9. Domingo Hergueta y Martín, La imprenta en Burgos y su provincia. Obra inédita. Tomo II, cuartilla 95. 
do de Religión (Valladolid, 1603) ${ }^{10}$, Gobierno de la familia y estado de las viudas y doncellas (Burgos, 1603) ", y desde luego su célebre catecismo, que parece haber sido publicado con el título de «Doctrina Christiana y documentos de crianza.

¿Cuándo vio la luz pública su Doctrina Christiana? La fecha corrientemente admitida es la de $1599^{12}$, pero hay razones para pensar en la existencia de alguna edición anterior.

En una carta del jesuita P. Gil González Aquaviva, escrita en Montilla el 23 de marzo de 1586 se queja de que «cada colegio y cada maestro de escuela de niños tiene su catecismo diferente y algunos muy largos, muy teólogos en los misterios de la Sma. Trinidad y Eucaristía. Dicénme que los compuso el P. Arias; que para hombres bien entendidos son difíciles y no sirven para escuelas de niños y gente ruda. Podríase ordenar que se escogiese un catecismo acomodado y que todos usasen de uno y no hubiese la variedad que ahora se ve. Tienen aquí el del P. Marcos Jorge y el de Castilla y otro del Obispo de Granada y el antiguo del Maestro Ávila» ${ }^{13}$.

¿Qué entender por el catecismo de Castilla? El P. Astrain y con él Daniel Llorente se inclinan por creer que «quiere decir el más célebre de España o sea el del P. Gaspar Astete» ${ }^{14}$.

Si la suposión fuera exacta habría que pensar en alguna edición, ampliamente difundida, en 1586. Ahora bien, sin basarnos en suposiciones, tenemos noticias seguras de al menos una publicación anterior a 1599.

Domingo Hergueta, en su obra inédita ya citada La imprenta en Burgos y su provincia, afirma que

«en el Ministerio de la Biblioteca Provincial de Burgos. Libro $1 .^{\circ}$. Minuta N. ${ }^{\circ} 20$, día $1 .^{\circ}$ de agosto de 1877 se dan las gracias por el Jefe de la Biblioteca D. Manuel Martínez Anibarro y Rives al Sr. D. Juan Argente, vecino de Burgos, por haber donado a la Biblioteca un volumen en $16 .^{\circ}$ prolongado impreso en Burgos en 1593 que es una de las primeras ediciones del Catecismo del P. Astete. Hoy día no existe allí dicho ejemplar» ${ }^{15}$.

10. El Libro Español, junio 1958, pp. 307-308.

11. Catálogo de la Biblioteca del Marqués de la Romana, p. 38, col. 2. ${ }^{\text {a }}$.

12. V. D. Llorente, l.c.; A. Jungmann, Catequética 4 . $^{a}$ ed. Barcelona, 1966, p. 33; J. CoLOMB, Manual de Catequética. Barcelona, 1971, pp. 67-68; L. CsonKA, Historia de la catequesis, en Educar, tomo 3. ${ }^{\circ}$ (Metodología de la catequesis), Salamanca 1966, p. 151, da la localización de Burgos, 1598 para la primera edición.

13. A. Astrain, Historia de la Compañía de Jesús de la Asistencia de España, Madrid 1912, tomo IV, p. 76

14. Astrain, l.c.; D. Llorente, Tratado elemental de Pedagogía Catequística, $10 .^{\mathrm{a}}$ ed. Valladolid, 1965, p. 529; Id., Historia de la Catequesis, en «Revista Catequística» 16 (1925), pp. 34-38.

15. D. Hergueta, l.c., tomo $2 .^{\circ}$ cuartilla 87. 
Esta nota nos habla con seguridad de la existencia de un ejemplar, hoy desaparecido, de una edición del catecismo de Astete realizado en Burgos en 1593.

Aún hay otro dato para poder deducir con seguridad la existencia de una edición del catecismo de Astete hecha con anterioridad. El mismo Domingo Hergueta al escribir sobre La imprenta en Burgos y su provincia nos habla de otra obra escrita por Gaspar Astete. Se trata de la Institución y Guía de la Juventud Christiana, obra dividida en dos partes, la primera editada en Burgos en 1592 , en $8 .^{\circ}$, y la segunda también en Burgos, en 1594, asimismo en $8 .^{\circ}$, dedicada a don Christóbal Vela y Acuña, arzobispo de Burgos. En el «prólogo del autor al piadoso y benévolo lector» afirma de los jesuitas que

«...entre otras obras de piedad que con el próximo se ejercitan una es enseñar la doctrina christiana y los principios de nuestra Fe y sus sagrados misterios a los niños y a otra gente ruda. Esto he yo cumplido muchas veces de palabra y también por escrito, sacando a la luz la doctrina christiana, que comúnmente se enseña a los niños; y el modo de rezar el Rosario de Nuestra Señora, con unas oraciones cotidianas, de que no pocas (por la bondad de Dios) se han aprovechado; aunque algunos impresores han enxerido el Rosario en otros libros y quitado o mudado el nombre como les ha parecido..." ${ }^{16}$.

No resulta arriesgado concluir de las expresiones de Gaspar Astete que con anterioridad a 1592 había publicado su doctrina o catecismo, y no precisamente un catecismo cualquiera, sino en forma resumida adaptada a la enseñanza de los niños; descubre además algunos de los añadidos o apéndices con los que ha querido complementar su escrito, aunque reconoce que el uso que algunos impresores han hecho en particular del Rosario no termina de satisfacerle. En cuanto al lugar de la impresión, lo más seguro es pensar en la ciudad de Burgos no sólo por su estancia en la ciudad sino también porque en Burgos, en la imprenta de Felipe de Junta publica la Institución y Guía de la Juventud Christiana, donde nos transmite la primera referencia cronológica segura de su catecismo.

\section{GABRIEL MENÉNDEZ DE LUARCA}

Hasta aquí lo que hace a la intervención directa de Gastar Astete en su obra. La difusión que fuera alcanzando y el afianzamiento a la hora de ser usada en la instrucción cristiana de los niños son, sin lugar a dudas, notables. Casi dos siglos después de la publicación de Astete, un nuevo personaje va a influir de forma definitiva en la configuración de su catecismo, tal como nos ha llegado. Se trata de don Gabriel Menéndez de Luarca. Si de Astete dispone-

16. D. Hergueta, l.c., tomo $2 .^{\circ}$ cuartilla 56 y ss. 
mos de pocas noticias, las que hacen referencia a Menéndez de Luarca son también escasas.

De él sabemos que había sido colegial en el de San Pelayo de la Universidad de Salamanca, y que en la misma Universidad había desempeñado las cátedras de filosofía y teología. Abandona su actividad docente para pasar a ser canónigo penitenciario de la catedral de Segovia. Su origen asturiano puede ser deducido por el figurar en su apellido el «de Luarca», que hay que interpretarlo más como patronímico que como segundo apellido. Ello queda corroborado porque en el momento de la toma de posesión de su beneficio rige la diócesis segoviana don Alonso Marcos de Llanes.

El 25 de noviembre de 1776 se procedió por el cabildo a la provisión de la penitenciaría, siendo elegido por 29 votos de los 30 votantes. El 28 del mismo mes recibía la colación canónica y tomaba posesión de la misma ${ }^{17}$.

El 10 de mayo de 1800 no puede asistir a la toma de posesión del nuevo deán, por encontrarse enfermo. La naturaleza de la enfermedad nos queda aclarada, pues el 30 de julio de 1802 pide dispensa por imposibilidad física, por encontrarse ciego. Aún debe continuar atendiendo a las explicaciones de moral por algún tiempo, ya el 2 de abril de 1805, después de haber deliberado sobre la conveniencia de poner un sustituto, el cabildo le comunica que «por ahora no se resuelva pero que se comunique al señor penitenciario para quietud de su conciencia que no asista a la explicación de moral en atención a que no hay discípulos, ni al confesonario». El 7 de enero de 1806 le comunican que «jamás piense en el confesonario ni en la explicación de moral, pues de todo quedaba exonerado». Muere el 28 de abril de 1812.

Su intervención en el catecismo de Astete nos viene confirmada de su propia mano en los dos catecismos que preparó sobre la base del texto de Astete. El que podríamos denominar "catecismo mayor» ${ }^{18}$ da la siguiente «razón de la impresión»:

«Porque no todos los Niños que estudien la Doctrina Christiana por el pequeño Catecismo del Padre Gaspar Astete, que anteriormente se imprimió añadido con varias preguntas, y respuestas, estarán satisfechos en llegando a edad adulta, con saber las cosas, que en él se contienen, y desearán instruirse más por extenso acerca de lo que deben creer, orar, obrar, y recibir; por tanto a fin de que los tales puedan satisfacer sus deseos, conforme a lo que en aquel

17. Practicamente la totalidad de los datos relativos a la persona de Gabriel Menéndez de Luarca nos han sido facilitados por don Hilario Sanz Sanz, archivero del cabildo segoviano.

18. Catecismo de la doctrina christiana escrito por el P. Gaspar Astete, y añadido para su mayor declaración con varias preguntas, y respuestas, por el Licenciado Don Gabriel.Menéndez de Luarca, Colegial que fué en el Insigne de San Pelayo de la Universidad de Salamanca, y Catedrático de Filosofía, y Teología en ella; y al presente Canónigo Penitenciario de la Santa Iglesia Catedral de Segovia; (...) En Valladolid en la Imprenta de Don Manuel Santos Matute. Año de 1787. 
ofrecí, sale aora (sic) a luz el mismo aumentado, no solamente con útiles preguntas, y respuestas, y una compendiosa explicación de la Bula de la Santa Cruzada; sino también con el Librito intitulado: Vida Christiana, o Práctica fácil de entablarla con medios, y verdades fundamentales; compuesto por el Padre Genónimo Dutari; por hallarse en él brevemente resumida la práctica, y norma de una vida verdaderamente Christiana, a que deseo aspiren todos los Fieles.

$Y$ aunque no pocos se maravillarán salga en estos tiempos habiendo casi un sin número de ellos en que los Fieles pueden aprender quanto en este se contiene; con todo, ya porque no faltaran algunos, que haviendo (sic) estudiado el primero, para perfeccionarse en la Doctrina, tengan más inclinación a usar de éste, que de otro, y ya porque con esto, por una parte o ninguno perjudicamos, ni dañamos; por otra a no pocos podemos ocasionar gran utilidad; sin detenernos en lo que se pueda decir, lo publicamos a honra, y gloria de Dios, y a fin de que los que lean se exciten a emprender una vida christiana, y no ignorando los medios conducentes para esto, vayan de virtud en virtud hasta llegar a la perfección, que es el camino seguro para la Gloria».

Se ve claramente que se trata de un catecismo para adultos donde están debidamente explicadas las cosas que de niños aprendieron de forma sucinta. Pretende satisfacer la necesidad mayor propia de la edad adulta, cuando las explicaciones dadas a los niños resultan a todas luces insuficientes. Tiene en cuenta a los muchos que estudiaron sobre el texto de Astete y para ellos está destinada esta obra, aunque no desconoce la existencia de otros libros similares.

El tono, la confección y el estilo del catecismo habla indiscutiblemente de los destinatarios adultos, y aunque sigue fielmente el esquema de Astete, amplía numerosísimamente las cuestiones allí planteadas, e introduce otras nuevas que están ausentes de un texto destinado a niños.

Está planteado siguiendo el sistema habitual de preguntas y respuestas — que podría resultar discutible tratándose de dirigirse a adultos - y las cuestiones se suceden sin solución de continuidad en cada una de las cuatro partes tradicionales del catecismo. No introduce nuevos epígrafes o divisiones que presenten una lectura sistemática, si siquiera en el caso, tan frecuente por otra parte, de seguir el orden de los artículos de la fe.

El fondo doctrinal que subyace en toda la obra tiende a completar las lagunas existentes en el texto de Astete, y con un marcado acento moral y doctrinal pretende no dejar vacíos en la formación religiosa.

Hay además un aspecto que conviene resaltar adecuadamente y que habla muy alto de la honradez de Gabriel Menéndez de Luarca: se trata de la diferenciación expresa y neta de lo que escribiera Gaspar Astete, distinguiéndolo de todas las añadiduras hechas por él. Todo lo de Astete va impreso en letra cursiva mientras que las adiciones que él ha introducido figuran en letra recta. 
De esta forma, aunque no nos advierta de una manera expresa de la distinción entre tipos de letra, llegamos al texto original que Astete escribiera ${ }^{19}$.

Hemos visto que en su prólogo habla de «el pequeño Catecismo del Padre Gaspar Astete, que anteriormente se imprimió, añadido con varias preguntas, y respuestas» y destinado a los niños. Confirma su intervención en otro texto anterior, puesto que con el presente intenta satisfacer los deseos de sus lectores «conforme a lo que en aquel ofrecí». Por lo tanto es forzoso concluir en la existencia de otro catecismo de Astete añadido por Gabriel Menéndez y destinado no a adultos, sino a niños, con anterioridad a la fecha de 1787 .

Aunque desconozcamos la fecha de esta edición del catecismo de AsteteMenéndez de Luarca, que podríamos denominar como «catecismo menor», quizá no haya que pensar en una diferencia de muchos años, especialmente si pensamos en que se dedicara a la corrección del Astete en su época de penitenciario de Segovia. Para confirmar esta sospecha, disponemos de un ejemplar del «catecismo menor» o para niños, impreso en 1788 y en el que figura también como penitenciario de Segovia. No hace en el mismo referencia a alguna edición anterior, pero a pesar de ser posterior en un año a su «catecismo mayor» (1787), el prólogo parece ser reproducido del que figurara en la edición primera, puesto que habla del «catecismo mayor» como un proyecto aún a realizar.

El «Prólogo al Lector» del ejemplar que nos ocupa ${ }^{20}$ nos ofrece, al igual que ocurría con la adaptación a los adultos, la razón de la impresión de este Catecismo:

«porque con la práctica de mi Ministerio he llegado, como a palpar la grande ignorancia, que no solamente en los niños, sino también en los adultos se halla de la Doctrina Christiana, particularmente en orden a las disposiciones, que se requieren, para recibir los Santos Sacramentos; y estar persuadido de que tan lamentable ignorancia, en muchas partes de nuestra España proviene de no estudiarse regularmente en ellas más que el Catecismo del P. Gaspar Astete, en el que se desean varias cosas necesarias, para que los Fieles se instruyan acerca de lo que deben creer, orar, obrar, y recibir. Por lo mismo juz-

19. De esta obra nos dice Juan M. ${ }^{a}$ Solá, El catecismo único en España, en «Razón y Fe» 15 (1906), pp. 318-319: «El primero que se metió a aumentar «con varias preguntas y respuestas» el Catecismo del P. Astete, fué el Lic. D. Gabriel Menéndez de Luarca, de quien tenemos dos diversos arreglos: uno muy lato (Valladolid, 1787: en 8. ${ }^{\circ}$, de 404 págs. s. 3 hojs. de port, etc.), de que apenas tienen noticia ni aun los bibliógrafos; y otro más breve (Valladolid, 1799), que es el que anda en manos de todos». Se puede ver en este trabajo que la fecha de 1799 para el breve no es totalmente exacta pues disponemos de una edición hecha en Valladolid en 1788.

20. Catecismo de la Doctrina Christiana escrito por el P. Gaspar Astete; y añadido para su mayor declaracion, con varias preguntas y respuestas, que se hallan entre estas señales por el Lic. Don Gabriel Menéndez de Luarca, Colegial que fue en el Insigne de San Pelayo de la Universidad de Salamanca y Catedrático de Filosofía y Teología en ella; y al presente canónigo Penitenciario de la Sta. Iglesia Catedral de Segovia. Con Licencia. En Valladolid en la Imprenta de la Viuda e Hijos de Santander. Año de 1788. 
gamos sería medio oportuno, para remediar de alguna manera tanto mal, dar a luz este mismo Catecismo añadido con algunas preguntas, y respuestas; me he determinado a executarlo; para que los que gustaren usar de él, puedan instruirse de lo que deben saber como Christianos.

$\mathrm{Y}$ aunque no dudo, que algunos quisieran saliese con más extensión, para que se consiguiese este fin, creyendo yo que esto podría ser motivo, para que no se estudiase por él la Doctrina; tuve por conveniente no dilatarme más en él; y para satisfacer el deseo de aquellos, darlo después a luz con más extensión; como lo executaré con el favor del Señor. Quiera, pues, su Magestad por su infinita bondad, y misericordia sea todo para honra y gloria suya, y provecho de los Fieles, a quienes encarecidamente suplico disimulen las muchas faltas, que en él se hallarán; y que me tengan presente en sus oraciones».

Este otro catecismo, más breve, dirigido a los niños con la sana intención de aminorar la ignorancia religiosa que había experimentado como consecuencia del estudio exclusivo del texto de Astete, es el que corrientemente se ha difundido, con la particularidad de que todas las añadiduras que hiciera Gabriel Menéndez van cuidadosamente anotadas en todo el texto colocando al principio y al final de cada una de ellas un asterisco, para poder distinguir al autor de cada afirmación ${ }^{21}$.

Después de las adiciones de Menéndez de Luarca en el Catecismo de Astete, coexistieron durante bastante tiempo ambas modalidades de catecismo, bien presentando los añadidos de Luarca o bien carentes de ellos. Un ejemplar del catecismo de Astete impreso en Valladolid en $1825^{22}$ carece de todos los añadidos de Menéndez de Luarca. Otros dos ejemplares que incorporan estas adiciones van acompañados de una nota final en la que advierten que en las respectivas imprentas de donde han salido se pueden encontrar indistintamente catecismos añadidos y sin añadir, a conveniencia de los usuarios ${ }^{23}$.

A pesar de todo, la incorporación de las adiciones de Gabriel Menéndez debió ir adquiriendo carta de naturaleza con tal fuerza que en la mayor parte de los textos conocidos no se hace mención ni se diferencia lo más mínimo. Algunos ejemplares llegan incluso a precisar en la portada que se encuentran incorporadas las añadiduras de Gabriel Menéndez de Luarca, pero en el texto no las diferencia de lo que Gaspar Astete escribiera.

21. Lo mismo hacen otras ediciones como la de Valladolid de 1845 (Imprenta de Juan de la Cuesta y Cía); Valladolid, 1848 (Imprenta de D. J. Pastor); Valladolid, 1887 (Imprenta de la Viuda de Cuesta e Hijos); Santander, 1899 (Imprenta de «La Propaganda Católica»); Santiago, 1920 (Tip. de El Eco Franciscano) y Guernica, s.f. (Imprenta Moderna).

22. Catecismo de la Doctrina Cristiana, y su breve declaración por preguntas y respuestas para la educación de los niños. Escrito por el P. Gaspar Astete. Con Licencia. Valladolid. Imprenta de H. Roldán. Año de 1825.

23. Dicha nota consta en las ediciones de Valladolid de 1845 y 1848 que figuran en la nota 21. Como curiosidad cabe añadir que en la misma nota anuncian que disponen para su venta de papel reglado en folio, cuartilla y pautado, así como libros «de latinidad» y libros devotos. 


\section{OTROS AÑADIDOS}

La intervención decisiva de Menéndez de Luarca sobre el escrito de Astete no fue ciertamente la única. Alguna otra mano anónima ha tenido que intervenir a lo largo del tiempo para justificar la presencia de algunas frases o determinadas preguntas de escasa importancia en el conjunto del texto.

Sabemos con seguridad que después de esa intervención anónima, el obispo de Valladolid Benito Sanz y Forés introdujo de nuevo ligeras modificaciones en el texto ya retocado, en orden a conseguir una más exquisita y afinada precisión de conceptos en ciertas preguntas que a su modo de ver no reunían la perfección necesaria o no se ajustaban a las nuevas disposiciones de la Iglesia. Así dispuesto el catecismo, fue declarado texto oficial para toda la provincia eclesiástica vallisoletana en $1886^{24}$, decisión que fue ratificada de nuevo en el concilio provincial de Valladolid de $1887^{25}$.

Las adiciones que introdujera Sanz y Forés no tuvieron una aceptación universal, aunque se incorporaran modificaciones similares, ya que no literales, en otras ediciones de más allá de la provincia eclesiástica propia ${ }^{26}$.

Son más las adiciones que se incorporaron en diversos lugares del catecismo de Astete por obra de varios autores (Hermenegildo del Río, Hermenegildo Tobías, Manuel Lasaleta, Remigio Vilariño...), en cada caso, en función de unos criterios variados y frecuentemente a impulsos de una acentuación de ciertos aspectos estimados subjetivamente como muy importantes. Por ello, la mayoría de las adiciones con este carácter parcial y local, apenas tuvieron trascendencia más allá de los límites de influencia de su autor.

24. «In primis declaramus Catechismum Diocesanum esse librum a R. P. Gaspar Astete S.J. conscriptum, sed iuxta exemplar, quod cum opportunis correctionibus et additionibus a Nobis approbatis, quam primum typis edendum curabimus, ad cujus normam, quae in posterum fient, editiones ordinari mandamus», en «Synodus Vallisoletana ad Excmo. ac Rvdmo. Domino D. Benedicto Sanz y Forés Dei et Apostolicae Sedis gratia archiepiscopo vallisoletano». Vallisoleti, 1888. Liber primus. Titulus. V, parr. I: «De Doctrina Christiana edocenda». (pp. 18-21).

25. "Ad unitatem formae et methodi in catechesibus totius provinciae a Benedicto XIV tantopere commeddatam, adhibeatur Catechismum a R.P. Gaspare Astete conscriptus, et ubique a longo iam tempore admissus, cum additionibus factis in novissima editione Vallisoletana a Rmo. Archiepiscopo probata, quem omnibus proponendum et utendum decernimus», en «Acta et decreta concilii provincialis Vallisoletani in alma metropolitana ecclesia celebrati diebus a XVI Julii ad I Augusti anno Dni. MDCCCLXXXVII". Vallisoleti 1899. Pars sexta. Titulus VII, parr. III: «De catechesii) (pp. 262-265).

26. Algunas" ediciones del catecismo hacen referencia y señalan entre asteriscos las adiciones que incorporara Sanz y Forés: así, una edición aparecida en Valladolid, en 1930 (Casa Santarén) y otras dos aparecidas también en Valladolid, sin fecha, igualmente en Casa Santarén. En una edición publicada en Madrid, sin fecha (Ed. Saturnino Calleja) consta que señalan con asteriscos las añadiduras de Sanz y Forés «y otros autores de nota».

Entre las ediciones que incorporan adiciones similares a las de Sanz y Forés cabe señalar las aparecidas en Burgos, en la Imprenta de Hijos de Santiago Rodríguez. Hemos localizado ocho ediciones distintas y otras tres que probablemente salieron de la misma imprenta, pero todas ellas van sin fecha. 
En cambio, quien operó una modificación notable en el texto del catecismo de Astete con la incorporación de los añadidos de Gabriel Menéndez de Luarca y de Sanz y Forés, fue Daniel Llorente. Su personalidad en el campo de la catequética española reciente es notoria. Desde su perspectiva de impulsor de los principios metodológicos de la catequesis detectó dos notables deficiencias en la confección del texto que llegaba a sus manos.

El primer defecto era la ausencia de incorporación de pregunta en la respuesta, con lo cual, al repetir ésta sin aquélla, la respuesta carecía de seńtido en sí misma, prestándose a conocer una respuesta, pero sin saber 'a qué se refería. Unido a ello iba el peligro de contestar a una pregunta con la respuesta que hacía referencia a otra pregunta distinta ${ }^{27}$.

El otro defecto que Daniel Llorente trataba de obviar era la forma de estudiar el catecismo. Se seguía un orden rectilíneo según el cual la única acomodación a la distinta capacidad de los niños consistía en la cantidad de preguntas aprendidas, siempre a partir del principio. Daniel Llorente, basándose en anteriores estudios acerca del orden cíclico, propone una graduación de las preguntas en función de la calidad o importancia intrínseca de las mismas; seleccionando un núcleo fundamental de cuestiones independientemente de su ubicación en el conjunto del catecismo. Dicho núcleo se va ampliando en años o ciclos sucesivos. Para distinguir la materia que habría de corresponder a cada ciclo adopta para cada uno de ellos un tipo determinado de letra que lo distinga de los demás, con lo cual se identifican fácilmente las cuestiones que había que aprender en cada nivel ${ }^{28}$.

La participación de Daniel Llorente en el perfeccionamiento metodológico del catecismo de Astete-Menéndez de Luarca-Sanz y Forés nos viene confirmada por él mismo cuando nos dice:

«Del antiguo Astete, añadido por Menéndez Luarca, hice antes del Congreso Catequístico de Valladolid (1913) una edición cíclica, que ha servido de pauta a casi todas las que se han publicado de este texto y de otros. La característica de dicha edición es el orden cíclico, pero sin cambio alguno más que el indispensable en el texto, salvo incluir la pregunta en la respuesta. Hasta en lo referente al precepto del ayuno y de la Bula procuré conservar el sa-

27. Daniel Llorente zita el caso siguiente: «La Santísima Trinidad, ¿quién es? -Es una señora llena de virtudes y gracias, que es Madre de Dios y está en el Cielo». He aquí -continúa diciendo- ias consecuencias de no incluir la pregunta en la respuesta. Preguntas ¿La Santísima Trinidad, quién es? Exigid que os contesten: La Santísima Trinidad es...», en Avisos a los catequistas, en «Revista Catequística» 3 (1912), pp. 247-248.

28. La primera edición publicada por Daniel Llorente del texto tradicional de Astete apareció en Valladolid en 1913, en la imprenta Casa Martín. Apareció con el título Catecismo de la Doctrina Cristiana escrito por el P. Gaspar Astete de la Compañía de Jesús dispuesto en orden cíclico.

Es precisamente la disposición tipográfica y la inclusión de la pregunta en la respuesta la que plagia la edición de Magisterio Español sin mencionar su procedencia. 
bor arcaico y el estilo del autor. Seguí en ello las normas que me trazó el Emmo. Cardenal Cos (q.e.p.d.); esta edición ha sido prescrita para la Provincia Eclesiástica de Valladolid por el Concilio Provincial (Decr. 255, parr. $\left.3 .^{\circ}\right)$ y se ha extendido bastante aun fuera de la Provincia» ${ }^{29}$.

Como se ve la aportación de Daniel Llorente al catecismo es muy notable desde el punto de vista metodológico, que hasta entonces había estado descuidado. No altera substancialmente el fondo teológico encerrado en el secular texto de Astete, pero perfecciona sus procedimientos en conformidad con los adelantos que en esta materia se había realizado en la fecha en que publica la primera edición ${ }^{30}$.

Tal ha sido, reconstruida a grandes trazos, la azarosa historia del texto que saliera de manos del P. Gaspar Astete. Los retoques, enmiendas, correcciones, matizaciones y especialmente los añadidos han ido configurando el texto hasta el punto de desfigurarlo respecto a su original. Precisamente por ello, y por una carencia de conocimientos adecuados, se ha venido englobando todo bajo la paternidad de un único autor, cuando la realidad es bien distinta de la suposición.

El presente estudio puede contribuir a matizar afirmaciones tan absolutas como se han hecho y a relativizar la autoridad para algunos indiscutible del $\mathrm{P}$. Gaspar Astete.

\section{ESTRUCTURA EXTERNA DEL CATECISMO}

La nota primera que salta a la vista en la confección del catecismo de Astete, y que ha sido respetada por las adiciones posteriores, es la formulación de la enseñanza siguiendo el procedimiento de las preguntas y respuestas. En ello Gaspar Astete es heredero de la forma de catequesis medieval que consistía fundamentalmente en la fijación de unas fórmulas que el catequizando había de retener de memoria. Desde la mera enumeración de las fórmulas exigidas, se pasó fácilmente a la enunciación de una pregunta cuya respuesta era precisamente la fórmula que el catequizando había de saber y repetir.

29. Informe de Daniel Llorente de 1942 dirigido al Nuncio Cicognani titulado Estado actual de la catequesis en España. Título VII. Textos de Catecismo. Inédito.

30. Resulta curioso observar cómo a pesar de la aportación positiva de Daniel Llorente en el uso del catecismo de Astete, no siempre fuera tenida en cuenta. Incluso en la misma imprenta donde publicaba el catecismo «dispuesto en orden cíclico» se publicó en 1920 un texto de Astete (Valladolid, 1920, Imp. Casa Martín) que no recogía ni el orden cíclico ni la inclusión de la pregunta en la respuesta.

Lo mismo ocurre en las ediciones publicadas en Valladolid a que remite la nota 26.

Otro tanto acontece al P. Arturo Alonso Lobo en su edición de Salamanca de 1977, en la que se manifiesta en desacuerdo con los «pedagogos modernos». ¿Será también «moderna» la edición preparada por Daniel Llorente en 1913? 
Tal procedimiento fue considerado como normal ${ }^{31}$ y fue universalmente aceptado en los catecismos. Astete lo adopta en forma exclusiva, de suerte que todo su catecismo está desarrollado en preguntas y respuestas. Incluso las formulaciones previas que se ajustaban a las antiguas Cartillas de catecismo y que en su texto están recogidas bajo el enunciado global de Introducción de la Doctrina Cristiana (Todo fiel cristiano, Padrenuestro, Avemaría, Credo, Salve, Mandamientos de la Ley de Dios y Artículos de la Fe) están Jestinados a ser igualmente retenidos de memoria, aunque no sean precedidos de ninguna pregunta. Otro tanto ha de afirmarse de lo que podríamos considerar como «apéndices», que más adelante detallaremos, y que tan sólo en algunos casos van seguidos de preguntas aclaratorias, pero nunca precedidos: son también destinados a la retención de memoria.

Ciñéndonos al cuerpo del catecismo y su repetición constante de preguntas y respuestas, podría dar la aparente impresión de un diálogo llevado entre dos personas, el que pregunta y el que responde, el catequista y el catequizando. Sin embargo hay un tercer personaje que asiste como testigo casi mudo a todo el diálogo y que sólo interviene en algunas ocasiones para hacer una reflexión de carácter piadoso. Así como el diálogo entre el catequista y catequizando está señalado en la mayor parte de los textos conocidos con las letras $P$ y $R$, (abreviaturas de Pregunta y Respuesta, o de Pregunto y Respondo), la intervención de este tercer y discreto personaje está identificada con la abreviatura de $M$. Son muy escasos los ejemplares que nos aclaran el significado de tal sigla, que corresponde a la denominación de Maestro ${ }^{32}$.

Se trata, pues, de un coloquio en el que el niño es interrogado por el sacerdote ${ }^{33}$ en presencia del maestro; éste último toma en ocasiones la palabra para hacer consideraciones pías o para invitar al niño a que continúe mostrando lo que ha aprendido ${ }^{34}$.

31. El procedimiento es normal cuando se trata de tomar la lección, pero es antinatural cuando se trata de aprender lo desconocido. Entonces lo normal es que quien no sabe pregunte. Es el procedimiento que usa Belarmino en su Dichiarazione piú copiosa. Daniel Llorente en su Tratado elemental de Pedagogía Catequística (10. ${ }^{\text {a }}$ ed.) Valladolid 1965 , p. 145 , nota 3 nos da noticia del mismo procedimiento en las instrucciones para primera confesión y comunión del apéndice del Concilio Provincial Romano de 1725 celebrado bajo Benedicto XIII. Ello obedece a que dicho concilio aconsejó el uso de la "Doctrina cristiana breve», de Belarmino.

32. En el «catecismo mayor» de Menéndez de Luarca, reseñado en la nota 18, figura descifrado en la p. 225. En las ediciones de Pamplona, 1934 (con adiciones de los obispos Uriz y Labairu y Muniz Pablos) y de Madrid y Barcelona (?), 1914 (Catecismo ilustrado dispuesto y arreglado por el P. Eduardo Teysseyre), se menciona expresamente al Maestro en todas sus intervenciones.

33. Se puede identificar con el sacerdote por el estilo general. Astete incluye 4 preguntas en que la contestación escueta es Sí, Padre, y 6 con la negativa No, Padre. Podría tratarse de un diálogo del niño con su padre natural, o con su padrino, denominado así por extensión.

34. Las intervenciones del Maestro son: al final de la primera parte: Bien decís, que a los doctrores conviene, y no a vosotros, dar cuenta por extenso de las cosas de la fe; a vosotros bástaos darla en los Artículos como se contienen en el Credo. Hablando de la imagen de la Virgen: 
El procedimiento del «diálogo a tres» no es original de Astete, quien se basa sin duda en antecedentes que han usado idéntico sistema. Ya había sido usado por Erasmo en su Inquisitio de fide y en la Explanatio, así como por Juan de Valdés al escribir el Diálogo de Doctrina Christiana, nuevamente compuesto por un religioso. Pero precedente más inmediato a Gaspar Astete lo constituía sin género de duda Constantino Ponce de la Fuente, quien en la Suma de doctrina christiana hace intervenir al joven Ambrosio en diálogo con su padrino Dionisio, que pregunta, resume y dirige la conversación; es testigo del diálogo y refleja la ignorancia religiosa y el carácter rutinario de las formas tradicionales el padre de Ambrosio, Patricio ${ }^{35}$.

Sobre este cliché familiar, discurre el diálogo que constituye la parte esencial del catecismo de Astete y las preguntas y respuestas van concatenadas siguiendo un esquema también preestablecido de dividir el contenido de la fe cristiana en cuatro partes ${ }^{36}$.

El esquema completo del catecismo de Astete es como sigue. Comienza por una Introducción de la Doctrina Cristiana, cuyo contenido ya hemos explicitado ${ }^{37}$. Tras ella viene la Declaración de la Doctrina Cristiana, cuyo contenido fundamental estriba en la condición de cristiano del catecúmeno y sobre la señal de la cruz. A ello sigue la División de la Doctrina Cristiana, que justifica las cuatro partes que constituyen el cuerpo de la obra. En la primera parte "¿se declara el Credo y los Artículos de la fe»; y aunque se sigue el orden deincidente de ambos, su contenido no está parcelado ni según los doce artículos tradicionales del credo ni según los catorce artículos de la fe. En la segunda parte «se declara lo que se ha de pedir y las oraciones de la santa Madre Iglesia):: incluye la explicación tradicional sobre el Padrenuestro además de la del Ave María, la Salve y una explicación sobre los ángeles. En la tercera parte «se declara lo que se ha de obrar»; consiste en una explicación recorriendo los mandamientos de la ley de Dios; en ella se encuentran integrados, sin marcar ninguna distinción que las frases introductorias del Maestro, los mandamientos de la Iglesia así como las obras de misericordia en su doble vertiente de espirituales y corporales. En la cuarta parte «se declaran los Sacramentos que se han de recibir». Una vez terminados los sacramentos, se insertan los pecados capitales y las virtudes contrarias; los enemigos del alma, de que hemos de huir; las virtudes teologales; las virtudes cardinales; los senti-

Pues lo mismo habéis de hacer a la imágenes de los demás Santos. Respecto al ángel de la guarda: Pues tenedle mucha devoción y encomendáos a él cada día, y Dedid las obras de misericordia. Además: Decid los Mandamientos de la santa madre Iglesia. Y al final de los novísimos: El Señor nos lleve a todos allá. El resto de esta última reflexión es obra de Gabriel Menéndez de Luarca.

35. Ver J.R. GERRERO, l.c., p. 43.

36. En su artículo El plan del catecismo y la concentración interna, publicado en «Sínite», 1 (1960), p. 135-142, Daniel Llorente habla de varios catecismo divididos en cuatro partes, así como de otros que se ajustan a otros planes en su división.

37. Ver p. 19. 
dos corporales; las potencias del alma; los dones del Espíritu Santo; los frutos del Espíritu Santo y por último, las bienaventuranzas. En este punto se marca como una diferencia, para incluir a modo de apéndices unas prácticas piadosas que constituyen una especie de devocionario ${ }^{38}$. En él se incluyen la Confesión o Yo pecador; el acto de contrición; la letanía de nuestra Señora, (no incluye los tradicionales misterios del rosario); el modo de ayudar a misa, y la Oración del Santo Sudario.

\section{ESTRUCTURA INTERNA DEL CATECISMO}

Vamos a practicar una especie de disección del catecismo de Astete, recorriendo al detalle cada una de sus partes, en orden a analizar las añadiduras de que ha sido objeto con posterioridad para cribar lo que salió originalmente de la pluma del P. Astete.

Para ello nos hemos servido de numerosas ediciones algunas de las cuales hemos reseñado ya. Especial importancia han tenido la del «Catecismo mayor» de Menéndez de Luarca (Valladolid 1787) y la del "catecismo menor» añadido por el mismo autor (Valladolid 1788), así como la edición sin las añadiduras de Menéndez de Luarca (Valladolid 1825). Constantemente las hemos cotejado con la última edición que Daniel Llorente publicara en Valladolid en 1957, que recoge todas las modificaciones anteriores además de las que él introdujo y que salió a la luz pública con la advertencia de «Edición provisional para los grados segundo y tercero".

Es preciso advertir en honor a la verdad que la tarea de reconstruir totalmente la historia de las ediciones del catecismo de Astete, del cual se habla de más de mil ediciones tendrá que ser objeto de una labor ardua y prolongada. A pesar de la reconstrucción parcial que hemos conseguido, al margen de error en la atribución de cada una de las partes a sus respectivos autores es mínimo y viene corroborado, salvo ligerísimas dudas, en la mayor parte de los casos.

A la vista de estos datos iniciamos el recorrido detallado por cada una de las partes que constituyen el catecismo.

38. Ya hemos recogido en la p. 8 el testimonio de Gaspar Astete que nos dice haber añadido al catecismo "el modo de rezar el Rosario de Nuestra Señora, con unas oraciones cotidianas», expresión ésta muy genérica que no precisa cuáles son con exactitud.

Juan M. ${ }^{2}$ Solá en el artículo citado, en «Razón y Fe» 16 (1906), p. 66, dice: «Desde el siglo XVII fue muy común hacer al Ripalda y Ästete diversas adiciones de unos, dos, tres y aun «cuatro tratacos muy devotos, en orden de ayudar a Missa; con el exercicio quotidiano para andar todo el día en oración sin dexar cada uno sus ocupaciones, con el acto de contrición», convirtiendo de esta manera el Catecismo en verdadero devocionario». Para el entrecomillado incluido en esta cita, remite en nota a «Ediciones de Alcalá, 1682. Madrid, imprenta de la Gaceta, 1766, etc. Vid. Sommervogel y Bibliografía madrileña de Pérez Pastor». 
La edición de Daniel Llorente se abre a modo de prólogo con un comentario que el P. Urrutia hiciera sobre el cuadro de Murillo «Los niños de la concha»" ${ }^{39}$, si bien está resumido por Daniel Llorente. Constituye una singularidad en las ediciones que él preparó y no está presente en otras ediciones.

\section{A. Introducción a la doctrina cristiana}

Ya hemos señalado anteriormente su contenido. Entre las fórmulas de fe, las oraciones y los mandamientos, ni Gaspar Astete ni Gabriel Menéndez incluyen el Gloria. Se trata de una adición posterior, cuya aparición es difícil de precisar. En cualquier caso es una adición muy reciente, puesto que en textos aparecidos a lo largo de todo el siglo XIX no figura el Gloria.

Posiblemente se trata de una adición de Daniel Llorente, ya que no consta en las primeras ediciones de su adaptación y solamente a partir de la sexta edición, en 1922, aparece el Gloria. A partir de esta fecha aparece en todas las ediciones por él preparadas, así como las que se hicieron con posterioridad, basadas en su adaptación.

Como curiosidad vale la pena resaltar que en una edición preparada en Astorga y aprobada por el obispo Antonio Senso Lázaro publicada en 1923, el texto del Gloria figura en latín, en tanto que las demás oraciones y fórmulas de fe aparecen en castellano.

\section{B. Declaración de la doctrina cristiana}

Esta parte consta de 21 preguntas, originales todas ellas de Gaspar Astete. De ellas, siete han llegado hasta la última edición de Daniel Llorente inalteradas tanto en las preguntas como en las respuestas ${ }^{40}$. Las demás han sufrido modificaciones por parte de Daniel Llorente para incluir la pregunta en la respuesta para hacer que ésta tuviera sentido en sí misma ${ }^{41}$.

Hay, pues, una respuesta, señalada en la nota anterior, que es enteramente ffuto de Llorente, modificando la escueta respuesta de Astete.

Otra modificación que introduce es la de sustituir el arcaísmo de «signar-

39. Publicado por Urrutia en el $n .^{\circ} 23$ de la Revista «El Catecismo de Santiago» (Ver «Revista Catequística», 5 (1914), p. 160-163). Daniel Llorente lo incluye a partir de la $7 .{ }^{\mathrm{a}}$ edición del catecismo por él retocado (1924).

40. Éstas son: «¿Qué entendéis por hombre de Cristo?»; «¿Por qué?» (refiriéndose a por qué es la señal del cristiano); "¿Cuáles son?» (Las dos maneras de usar la señal de la cruz); las dos veces que señala Mostrad cómo (para signar y santiguar); « ¿Por qué tantas veces?» (por qué hay que usarla tantas veces) y Cuando adoráis la Cruz, ¿cómo decís?

41. Como más llamativas podemos citar dos: $1 .^{\text {a }}$ respuesta en Astete: en dos; en Daniel Llorentę: El cristiano ha de usar esta señal de la Cruz de dos maneras. 2. ${ }^{a}$ Astete: Sí, Padre; Daniel Llorente: La Cruz tiene virtud contra nuestros enemigos. 
se en los pechos» por la fórmula más actualizada de «el pecho» ${ }^{42}$. Hay también una nota de Daniel Llorente invitando a introducir una variedad en el método evitando las preguntas y haciendo del diálogo un monólogo.

Alguna otra modificación de Daniel Llorente relativa a la adaptación del lenguaje arcaico carece de importancia.

\section{División de la doctrina cristiana}

Consta de seis preguntas procedentes todas de manos de Astete. Daniel Llorente introduce la modificación de incluir la pregunta en la respuesta.

En la primera pregunta aparece la primera adición de Gabriel Menéndez. Gaspar Astete la formula así:

¿Cuántas cosas está obligado a saber el cristiano cuando llega a tener uso de razón?

Menéndez de Luarca matiza:

¿Cuántas cosas está obligado a saber $y$ entender el cristiano cuando llega a tener uso de razón?

La justificación la encontramos en el «catecismo mayor» de Gabriel Menéndez, donde a este propósito dice:

«Para manifestar, que no se cumple con esta obligación sabiéndolas solo de memoria, y sin inteligencia; sino que es menester entenderlas substancialmente: esto es percibir, y penetrar lo que significan, o quieren decir» ${ }^{43}$.

Vemos apuntar ya su interés por la pureza íntegra que no se puede exponer a dejar cabos sueltos o imprecisiones. Tal interés de Gabriel Menéndez de Luarca estará presente, como veremos, en todas sus intervenciones.

\section{Primera parte de la doctrina cristiana}

Pasemos a la primera parte cuyo contenido está constituido por el credo y los artículos de la fe, y que podríamos definir como la parte más dogmática de todo el catecismo.

En la edición de Daniel Llorente que nos sirve de guía, la primera parte está constituida por 64 preguntas además de una reflexión final ${ }^{44}$. Ésta ha salido de la pluma de Astete.

42. Precisamente el médico Manuel H. Huerta escribe el 19 de octubre de 1935 a Daniel Llorente sugiriéndole esta enmienda que ya había introducido: Otra enmienda sugerida es la de hablar de Dios Creador, reservando al término criador, criar para el cuidado de los ạnimales.

43. L. C., p. 21 .

44. Hay además una nota propia de Llorente en la que advierte la conveniencia de variar el orden de las preguntas para hablar de que no son tres dioses después de haber hablado de cuáritas personas hay en Dios. Esto lo hace en función de la selección de materia que reserva para el estu- 
No así la totalidad de las preguntas, pues aparte de la consabida modificación de Daniel Llorente de incluir la pregunta en la respuesta, hay 13 preguntas que no son de Astete.

Quedan así 51 preguntas de Astete, a las que se han añadido 13 más (aproximadamente un $25 \%$ ). Las preguntas originales del P. Astete no se libran en todos los casos del afán por la precisión que anima a Menéndez de Luarca. Señalemos las tres redacciones de una pregunta de Astete.

Astete ¿Son tres Dioses? No, sino un solo Dios verdadero.

M. de Luarca: ¿Son tres Dioses? No, sino un solo Dios verdadero, como también un solo omnipotente, un sólo eterno y un solo Señor.

D. Llorente: ¿Son tres Dioses? No son tres Dioses sino un solo Dios verdadero, como también un solo omnipotente, un solo eterno y solo Señor.

A otra pregunta de Astete donde razona la causa de la muerte de Cristo para librarnos «del pecado y de la muerte», Menéndez de Luarca añade puntillosamente: «...de la muerte eterna».

De las 13 preguntas añadidas a la primera parte de la doctrina cristiana, 12 son de Gabriel Menéndez de Luarca mientras que una no lo es. Vayamos primero con ésta.

Se trata de la pregunta que está formulada así: «Cuáles son las notas o caracteres de la Iglesia verdadera?». Después de haber hablado de la comunión de los santos y de haber ofrecido una definición de la Iglesia, Astete consagra una sola pregunta más a la Iglesia en la persona de su primer representante, el Papa. Por ello, algún corrector anónimo cuyo nombre no hemos podido averiguar estimó que la enseñanza eclesiológica era muy reducida y que había que hacer una reflexión incluyendo a la Iglesia como cuerpo constituido. Para ello se fijó, con indudable estilo apologético, en las notas que distinguen a la Iglesia verdadera de otras comunidades de creyentes no incluidas en la Iglesia ${ }^{45}$.

Esta pregunta no siempre ha sido formulada de una manera fija en todos los textos sino que se encuentra con ligeras variantes de formulación en los textos aparecidos sin fecha en Burgos (imprenta de Hijos de Santiago Rodríguez), en el de Valladolid de 1884 (Editorial Miñón), Valladolid, 1888 (Editorial Santarén), Bilbao, 1893 (Editoral Mensajero) y Santander, 1899

dio en la clase $1 .^{\text {a }}$ de su plan cíclico que explica en su folleto titulado Programa de instrucción religiosa (Valladolid, 1913).

45. Tal modificación consta en las ediciónes de Valladolid, 1884. (Imp. de Leonardo Miñón), Valladolid, 1888 (Imp. de F. Santarén), Bilbao, 1893 (Imp. del Corazón de Jesús), Santander, 1899 (Imp. «La Propaganda Católica»), pero no en el texto sino én el comentario a pie de página a cargo del P. Manuel La Saleta, Astorga, 1923 (Imp. de N. Fidalgo), en las ediciones hechas por Daniel Llorente en Valladolid, en la de Madrid, 1915 y otras dos de Madrid, s.f. (Ed. Saturnino Calleja) y en las de Burgos, s.f. (Imp. Hijos de Santiago Rodríguez). 
(añadido por Manuel Lasaleta). La respuesta que ofrece el texto de Bilbao de 1893 es la más parecida a la que encontramos en el texto de Llorente sobre el que nos basamos.

Las 12 preguntas originales de Gabriel Menéndez son: Según esto, ¿cuántas naturalezas, entendimientos y voluntades hay en Dios?; ¿Cuántas personas hay en Dios?; ¿Para qué fin ha criado Dios al hombre?; ¿Cuántas naturalezas, voluntades y entendimientos hay en Jesucristo?; ¿Y cuántas personas y memorias?; ¿Por qué decís sobrenatural y milagrosamente? (aludiendo a la concepción de Jesús); la célebre pregunta Pues ¿cómo se obró el misterio de su concepción?; ¿Y cómo nació milagrosamente?; Pues, ¿cómo incurrimos en ella? (la muerte, consecuencia del pecado), ¿Pues hay más de un infierno? ${ }^{46}$; ¿Y qué cosas son? y finalmente, $Y$ antes del fin del mundo ¿serán los hombres juzgados?

Sólo con la lectura de los enunciados de las preguntas puede hacerse una valoración primera de las añadiduras incorporadas por Gabriel Menéndez de Luarca. Algunas preguntas, como la que mira por el sentido de la creación del hombre, pueden ser más útiles e interesantes para nutrir la fe de los niños destinatarios del catecismo. En cambio, otras sutilezas como el número de naturalezas, entendimientos y voluntades que hay en Dios o en Jesús hecho hombre, escapan al interés directo de los niños y aun de los adultos.

Haciendo referencia a los adultos, bueno será recordar que algunás de las preguntas, así como las respuestas introducidas en el catecismo de los niños están casi o totalmente al pie de la letra en el «catecismo mayor» de Menéndez de Luarca. Esto sucece por ejemplo con la respuesta a Pues ¿cómo se obró el misterio de su concepción? En las entrañas de la Virgen María... ${ }^{47}$. A la vista de esto cabe concluir que si la misma respuesta es presentada a los niños y a los adultos necesariamente ha de estar desproporcionada para uno de los dos grupos, pero no puede ser que cuadre a ambos.

No son las de Gabriel Menéndez las únicas adiciones que aparecen en esta primera parte de la doctrina cristiana, puesto que en ella constan las tres primeras enmiendas introducidas por Sanz y Forés. La primera enmienda consiste en añadir una frase a la respuesta que Gaspar Astete ofrecía acerca de quién es Dios. Sanż y Forés estimó que la respuesta estaba incompleta y en consecuencia añadió a las notas que sobre Dios había señalado Astete la de que es premiador de buenos y castigador de malos.

Si consideramos que Menéndez de Luarca había introducido con anterioridad una pregunta sobre el juicio de Dios y su resultado, parece fuera de

46. Hay un detalle original de Menéndez de Luarca en la respuesta a esta pregunta y que ha sido suprimido en algunas ediciones posteriores. Se trata de la localización geográfica de los infiernos al afirmar: "Hay cuatro infiernos en el centro de la tierra, y se llaman...».

47. G. MENENDEZ DE LuARCA, l.c., p. 35. Hay que señalar que en esta obra no se cine al mismo orden con que figuran las preguntas en el «catecismo menor». 
lugar el apéndice de Sanz y Forés. Por otra parte acumular en una respuesta en plan exhaustivo todas las notas en torno a Dios prolongaría sin sentido la respuesta para convertirla en un tratado teológico.

La segunda enmienda de la mano de Sanz y Forés obedece a la de la actualización de la evolución del dogma católico. El 8 de.diciembre de 1854 Pío IX había definido el dogma de la Concepción Inmaculada de María ${ }^{48}$. Tal aseveración no había sido recogida en las ediciones anteriores ${ }^{49}$. Menéndez de Luarca había explicado que todos incurrimos en la muerte eterna,

«pecando nuestro primer padre Adán en quien todos pecamos», a lo cual añade Sanz y Forés:

«a excepción de la Inmaculada Virgen María que fue concebida en gracia santificante, por singular privilegio».

Otro tanto ocurría con la definición de infalibilidad pontificia dilucidada en el curso del Concilio Vaticano I ${ }^{50}$ y que tampoco había sido recogida por anteriores textos de catecismo ${ }^{51}$. Astete:

Sanz y Forés modifica, matizándola, la respuesta que había formulado

Astete:

«El Sumo Pontífice de Roma, Vicario de Cristo en la tierra a quien todos estamos obligados a obedecer».

Sanz y Forés: El «Sumo Pontífice de Roma, Maestro infalible en las cosas tocantes a la fe y a las costumbres cuando enseña la Iglesia universal, Vicario de Cristo en la tierra a quien todos estamos obligados a obedecer».

48. Bula Ineffabilis Deus. Ver: Denzinger-Schönmetzer, ed. 32. ${ }^{a}$, n. 2803.

49. Nos referimos a las ediciones usuales del texto de Astete. En cambio en el «catecismo mayor» de Menéndez de Luarca dice: «¿Según esto algunos fueron concebidos, y nacieron sin pecado original? - Sí, Padre, es de fe que Christo nuestro bien fue concebido, y nació sin él, y la Iglesia nuestra Madre piadosamente cree, que la SS. Virgen María gozó de igual privilegio, y excepción: más exceptuando nuestro Salvador, y su SS. Madre todos los demás fueron, y son concebidos en pecado original; aunque algunos Santos como Jeremías, y el Bautista nacieron sin él por haver (sic) sido santificados en el vientre de sus Madres» (L. C., p. 144).

Parece que el sentido de la palabra «cree» en la mentalidad de Gabriel Menéndez equivale a «acepta», y no al sentido dubitativo de «opina». A ello da pie la distinción que introduce entre Jesús y María y algunos santos (Jeremías y Juan Bautista). Queda, con todo, un margen de duda, porque al hablar expresamente de María (l.c., p. 63-64) nada dice de su concepción inmaculada. $\mathrm{Ni}$ tampoco ha trascendido nada de ello al «catecismo menor de Menéndez de Luarca.

Otros catecismos que recogen la concepción inmaculada, precisando además la fecha de la definición son las ediciones de Burgos, s.f. (Imp. Hijos de Santiago Rodríguez) y dos ediciones de Madrid, una de 1915 y otra sin fecha (Ed. Saturnino Calleja).

50. Constitución Pastor Aeternus. Ver: Denzinger-Schönmetzer, ed. 32., n. ${ }^{\circ}$ 3073-3075.

51. También había sido incluida en las ediciones de Burgos y en las de Saturnino Calleja recogidas en la nota 49. Además lo incluye también otra edición distinta de Madrid, s.f., (Ed. Saturnino Calleja). En todas las ediciones indicadas hay además una pregunta sobre la fecha de la 


\section{E. Segunda parte de la doctrina cristiana}

En ella se trata de la oración, y muy especialmente del tratado tradicional de los catecismos y cartillas que versaban sobre el Padrenuestro.

La última edición de Daniel Llorente nos presenta para la segunda parte un total de 42 preguntas, más dos reflexiones. Éstas, puestas en boca del maestro que asiste al diálogo entre el catequista y catequizando, invitan a tener respeto a las imágenes de los santos ${ }^{52} \mathrm{y}$ a guardar devoción al ángel de la guarda.

La mayor parte de las preguntas (37 en total) son originales de Gaspar Astete y sólo 5 obedecen a la pluma de Menéndez de Luarca. De ellas cuatro hacen referencia a la oración.

Astete se había contentado con mostrarnos que Cristo nos había enseñado a rezar y nos había dicho lo que era la oración. No contento con esto, Menéndez de Luarca hace una serie de precisiones sobre la oración: ¿De cuántas maneras es la oración?; ¿Qué cosa es la mental?; ¿Qué cosa es la vocal? y ¿Cómo se ha de orar? Algunas de las explicaciones que da se encuentran desproporcionadas para los niños, máxime si pensamos que casi con las mismas palabras hace la explicación de la oración mental para los adultos ${ }^{53}$.

La otra pregunta añadida por Menéndez de Luarca y que escapa por su sutileza a las mentalidades infantiles remite a Y Cristo en cuanto hombre, ¿dónde está? porque Astete venía hablando de que la oración es hablar con Dios y se pregunta dónde está Dios. La sutileza de Gabriel Menéndez en el texto de los niños parece a todas luces fuera de lugar ${ }^{54}$.

Hay en esta segunda parte un ligerísimo añadido de Sanz y Forés, quien en consonancia con la definición del dogma de la Inmaculada Concepción no se contenta con la descripción que Astete había hecho de María como «una Señora llena de virtudes, que es madre de Dios y que está en el cielo». Él la re-

declaración. Nada dice Menéndez de Luarca en su «catecismo mayor» sobre la cuestión de la infalibilidad.

52. También modifica Menéndez de Luarca la primera reflexión. En Astete consta así: «Pues lo mismo habéis de hacer a las imágenes de los demás Santos»; Gabriel Menéndez dice: «Pues lo mismo habéis de hacer a las imágenes de los Santos y a sus reliquias».

53. G. MenÉndez de LuARCA, l.c., p. 54-55.

54. En su «catecismo mayor» (l.c., p. 58-60) Gabriel Menéndez dedica una serie de preguntas para aclarar la afirmación de Astete. Sobre su presencia en todo lugar precisa para los adultos que se encuentra por esencia, presencia y potencia; amplía la idea con la presencia especial de Dios en el cielo y en la Eucaristía y añade otra cuestión sobre el modo especial de la presencia de Dios en los Justos por gracia (...), en los Bienaventurados por gloria (...) y en la humanidad de Christo nuestro Señor. Termina la reflexión sobre la presencia de Dios preguntándose dónde estaba antes de crear el mundo, y finalmente con la pregunta que ha pasado al texto de los ninos: $Y$ Christo en quanto hombre, en dónde está? La pregunta tiene idéntica respuesta en ambos textos. 
toca diciendo que «es una Señora llena de virtudes y gracia, que es madre de Dios...» ${ }^{55}$.

Astete habla de que la mejor de todas las oraciones es el Pater noster. Sanz y Forés lo aumenta con la traducción: el Pater noster o Padre Nuestro.

La aportación de Llorente en la segunda parte del catecismo es la usual con la introducción de la pregunta en la redacción de la respuesta para que tenga sentido completo por sí misma.

\section{F. Tercera parte de la doctrina cristiana}

El P. Astete dice que en ella se declara lo que se ha de obrar. Está contenida, por tanto, la doctrina relativa a los mandamientos de la Ley de Dios, la de los mandamientos de la Iglesia, y las obras de misericordia. Por llevar algo de orden en la lectura crítica que estamos haciendo nos fijaremos separadamente en cada uno de estos tres apartados.

\section{Mandamientos de la Ley de Dios}

La edición de Daniel Llorente, sobre la que nos apoyamos, incluye un total de 51 preguntas para los mandamientos de Dios. Sorprendentemente, tan sólo 25 han brotado de la pluma del P. Gaspar Astete. Son por tanto 26 preguntas las que se han añadido a su escrito configurando una amalgama en que los añadidos superan al original. Solo este dato tendría que ser lo suficientemente expresivo como para ponernos en guardia: ya no se trata de pequeños retoques como los que hasta ahora veníamos contemplando. Se ha operado en la obra de Astete una modificación substancial lo bastante abultada como para no pasarla por alto a la ligera. Además, una respuesta de Astete queda también notablemente modificada.

De las 26 nuevas preguntas, la mayor parte son obra de Gabriel Menéndez de Luarca, hasta un total de 24 preguntas; solamente dos no provienen de él.

\section{1. ${ }^{\text {er }}$ mandamiento}

A él están dedicadas seis preguntas provenientes todas de Astete. Además de las modificaciones metodológicas de Llorente incluyendo en la respuesta la pregunta, hay una modificación notable en una de las dos preguntas que Astete dedica a explicar en qué casos se peca contra el primer mandamiento. Astete formula así la respuesta:

«(peca) el que adora o cree en ídolos o dioses falsos».

55. Algunas ediciones como las de Burgos s.f. (Imp. Hijos de Santiago Rodríguez) y Madrid, 1915, más otras dos de Madrid, sin fecha (Ed. Saturnino Calleja) preguntan por la fecha de la definición del dogma. 
A pesar de que Astete dedica además otra pregunta a señalar también formas de pecados contra el primer mandamiento, Menéndez de Luarca considera totalmente insuficiente la respuesta que Astete ofrece y la redacta así:

«El que adora o cree en ídolos o dioses falsos; el que cree alguna cosa contra la fe o duda de alguno de sus misterios, o ignora los necesarios; el que no hace, cuando está obligado, actos de Fe, Esperanza y Caridad, o desconfía de la misericordia de Dios, o recibe indignamente algún sacramento».

En tan notable adición vemos despertar con toda su fuerza el espíritu moralista de quien era canónigo penitenciario en Segovia. Resulta evidente su preocupación casuística, así como el dejar establecida una lista lo más completa posible de pecados (al estilo de los medievales «Espejo de confesión»o «confesionales») y favorecer la distinción específica prescrita en Trento ${ }^{56}$.

La predominancia del moralista aparecerá innegable a partir de ahora prácticamente en todas las aportaciones de Gabriel Menéndez. Tal estilo y la cantidad de sus aportaciones desfigurarán notablemente lo escrito por Astete dándole un estilo moralizante que está ausente del escrito original.

Todavía formula Astete otra pregunta sobre posibles pecados contra el primer mandamiento. Esta vez es Llorente quien puntualiza la respuesta de Astete. La de éste decía que peca,

«el que cree en agüeros, o usa de hechicerías o cosas supersticiosas».

Después de salir de la manos de Llorente queda así:

«El que cree en agüeros, o usa de hechicerías o cosas supersticiosas; $y$ el que entra en sociedades secretas, lee, retiene, presta o vende libros prohibidos».

\section{2. ${ }^{\circ}$ mandamiento}

De las 13 preguntas dedicadas a él, sólo cuatro son de Astete y nada menos que nueve son de Menéndez de Luarca. Astete formuló las siguientes: ¿Cuál es el segundo?; ¿Quién se dice jurar en vano?; ¿Y es pecado jurar por las criaturas?; y ¿Qué remedio hay para no jurar en vano? Es obvio que en la intención del $\mathrm{P}$. Astete hay un afán de exposición muy simple e incluso de edificación buscando una solución positiva y evangélica al problema de jurar en vano.

A Menéndez de Luarca debemos ocho preguntas sobre el juramento y una sobre la blasfemia. Contempla detenidamente los tres defectos que puedan existir en el juramento y que no había señalado Astete, y da por sepa-

56. Conc. Tridentino, sesión Xiv, cap. 5 «De confesior.e». Denzinger-Schonmetzer, ed. $32 .{ }^{a}$, n. ${ }^{\circ} 1679$ y ss., además del canon respectivo, n. ${ }^{\circ} 1707$. 
rado la calificación moral que cada uno merece; añade otra pregunta sobre el juramento promisorio y el voto y la última la dedica a la blasfemia ${ }^{57}$.

Vuelve a aparecer el Menéndez de Luarca moralista y su matización ${ }^{58}$. Sin embargo es aún considerado insuficiente por Sanz y Forés que quiere poner los puntos sobre las íes en una respuesta. Menéndez de Luarca había dicho de la obligación de quien jura o hace voto o promesa:

«Sí, Padre, el no cumplirla, o dilatarla notablemente es pecado mortal, siendo la materia grave».

La interpolación de Sanz y Forés suministra un matiz nuevo:

«...y el no cumplirla o dilatarla notablemente sin causa suficiente, exponiéndose a no poder cumplirla, es pecado mortal...»

Nos engolfamos así en una casuística que podría ser indefinida y que dudamos muy seriamente pueda conectar con los centros de interés de los niños respecto al segundo mandamiento y los posibles pecados contra el mismo. Nada hay que decir sobre no hacer aquí presente la afirmación positiva del Padrenuestro: «Santificado sea tu nombre».

\section{3. ${ }^{\circ}$ mandamiento}

El tercer mandamiento está casi intacto repecto al original de Astete. Además de los añadidos de orden metodológico que introduce Daniel Llorente, hay una sola pregunta adicionada a las dos que formulara Astete. Esta pregunta es obra de Gabriel Menéndez. Astete, después de haber enunciado el mandamiento tercero, se interesa por la parte positiva de su cumplimiento: ¿Quién santifica las fiestas?; en cambio, Menéndez de Luarca introduce su cuno de moralista para preguntar: ¿Y cómo peca el que trabaja sin necesidad en las fiestas? De nuevo comprobamos que sus respectivos puntos de vista son distintos.

\section{4. ${ }^{\circ}$ mandamiento}

Ello queda aún más patente en las preguntas relativas al cuarto mandamiento. De las siete que figuran en la edición de Daniel Llorente en que nos basamos, sólo tres obedecen a la pluma de Astete. Se ha preocupado de enunciar el mandamiento, de preguntar ¿quién honra a los padres? y de extender el

57. El enunciado de las preguntas de Gabriel Menéndez es: ¿Qué es jurar sin verdad?; ¿Y cómo peca el que jura sin verdad, o con duda de si lo que jura es verdad?; ¿Qué es jurar sin justicia?; ¿Qué es jurar sin necesidad?; ¿ Y qué pecado es éste?; Y el que jura o hace voto o promesa de hacer alguna cosa buena, ¿está obligado a cumplirla?; ¿Cómo se jura por las criaturas?; ¿Y se prohibe alguna cosa más en este mandamiento?

58. En el «catecismo mayor» dedica muchas más cuestiones lógicamente (l.c., p. 73-80) a lo relativo al juramento, el voto y la blasfemia. 
concepto restringido de "padres» a todos aquellos constituidos de alguna manera en autoridad: ¿Quiénes otros son entendidos por padres?

Gabriel Menéndez no se conforma con esto. Las cuatro preguntas que él añade van a matizar o añadir alguna cuestión. El honrar a los padres queda matizado y aclarado desde el punto de vista moral con la pregunta: ¿Quiénes pecan mortalmente contra esto? Pero no es aún suficiente puesto que la explicación de Astete no dice nada respecto a las obligaciones que los padres tienen respecto a sus hijos. En consecuencia, añade tres preguntas más: $Y$ en este mandamiento, ¿se comprenden más obligaciones que las de los hijos para con los padres?; ¿Cuáles son éstas? y finalmente ¿Cómo pecan los que faltan a ellas?

De nuevo nos queda la duda de si tales preguntas son adecuadas y encuentran su lugar oportuno en un catecismo "para niños». Encuentran su lugar apropiado en el texto para mayores ${ }^{59}$.

\section{5. ${ }^{\circ}$ mandamiento}

Las preguntas que formula Astete para el quinto mandamiento son escuetas y se ciñen a su enunciado y una sucinta explicación: ¿Cuál es el quinto? y ¿Qué se manda en este mandamiento?

No contento con una presentación tan esquemática y que matiza tan poco los posibles pecados que se cometen contra el quinto mandamiento, Menéndez de Luarca añade una serie de preguntas para completar, desde su enjuiciamiento de moralista, la explicación necesaria para la compresión del precepto divino. Sus preguntas son: ¿Y quién peca mortalmente contra este mandamiento?; ¿Qué cosa es maldecir?; ¿Y qué pecado es maldecir?; ¿Y si es sin tal deseo? (porque en la respuesta anterior ha aludido a la gravedad de maldecir con deseo de mal grave); ¿Pues quiénes pecan mortalmente maldiciendo sin tal deseo?; ¿Y por qué así?

Volvemos a comprobar que las adiciones de Menéndez de Luarca (seis preguntas) superan en cantidad a lo escrito originalmente por el P. Astete (dos preguntas). Pero no sólo es la cantidad lo importante. Astete ha estimado suficiente para los ninos el recordar las obligaciones principales que conlleva el cumplimiento del precepto, aunque dichas obligaciones las haya formulado negativamente (no hacer mal a nadie, ni en hecho, ni en dicho, ni aún por deseo). Menéndez de Luarca, como moralista, insiste más en los pecados que se pueden cometer, buscando hacer una lista lo más completa posible y que no dejara lugar a dudas en la conducta del cristiano.

Las adiciones de Daniel Llorente, son las usuales de incorporar la pregunta en la redacción de la respuesta.

59. G. MENÉNDEZ DE LUARCA, l.c., p. 83-84. 


\section{$6{ }^{\circ}$ y $7 .{ }^{\circ}$ mandamientos}

Al igual que ocurría con el quinto, Astete se limita a recordar el enunciado de cada uno de los dos mandamientos, y a continuación inserta la misma pregunta que ya había hecho para el quinto mandamiento: ¿Qué se manda en este mandamiento? No dice más de cada uno de ellos considerando que es suficiente para la presentación de los mismos a los niños.

Menéndez de Luarca añade una pregunta para el sexto mandamiento (¿Quiénes pecan mortalmente contra este mandamiento?) y dos para el séptimo (la primera igual en formulación que la añadida para el sexto mandamiento y la segunda que dice así: Y los que en esto hacen daño al prójimo de cualquiera manera que sea, ¿quedan con alguna obligación?).

No es necesario insistir en los mismos conceptos ya expresados de los distintos puntos de vista con que Astete y Menéndez de Luarca enfocan sus respectivas aportaciones.

\section{8. ${ }^{\circ}$ mandamiento}

Respecto a este mandamiento, Gaspar Astete repite el cliché de dos preguntas tal como había hecho en los mandamientos quinto; sexto y séptimo (cuál es el mandamiento y qué se manda en él). Pero además añade otra pregunta: ¿Quién quebranta este mandamiento? Completa algo más la exposición que pretende hacer de él. Ahora bien, resulta llamativo que una pregunta tan genérica y que podría haber sido enunciada por igual para todos los mandamientos, (con las naturales peculiaridades en la respuesta relativa a cada uno) sólo figure en el octavo.

Solamente en el primer mandamiento, en el que son mayoría las preguntas originales de Astete, se preocupa de ver qué pecados pueden ocasionar una transgresión del mandamiento. Además en el primer mandamiento, lo relativo a la transgresión y al pecado contra el primer mandamiento está desdoblado en dos preguntas ${ }^{60}$.

Llama la atención el que Astete dedique tan poco interés hacia la cuestión de los pecados que se pueden cometer en cada mandamiento.

Gabriel Menéndez de Luarca suple en todos los casos tal omisión. También en el octavo mandamiento, a pesar de la inclusión de una pregunta de Astete relativa a los pecados específicos al mismo, añade Gabriel Menéndez otra pregunta para matizar algunas cuestiones referentes a la obligación de restituir la fama: Y el que al projimo infama gravemente diciendo de él algún delito falso, o verdadero, pero oculto, echándole en cara sus defectos ¿queda con alguna obligacion? El afán matizador de Gabriel Menéndez le lleva a diferenciar

60. Las preguntas del primer mandamiento son: ¿Quién peca contra esto? y ¿Quién más? 
en el mismo enunciado de la pregunta la distinción entre calumnia y difamación.

Las adiciones de Daniel Llorente incluyen las de orden metodológico para facilitar el sentido completo de las respuestas. Hay además un matiz de índole moral introducido por él precisamente en la respuesta a la única pregunta de Gabriel Menéndez en este mandamiento. Menéndez habla de la obligación de restituirle la honra o fama que le ha quitado. El inciso de Llorente dice que quien ha faltado al octavo mandamiento tiene «la obligación de restituirle y satisfacerle la honra o fama que le ha quitado».

\section{9. ${ }^{\circ}$ y $10 .^{\circ}$ mandamientos}

En relación con estos dos mandamientos, resulta curioso comprobar que el P. Astete haga una sola pregunta que engloba a ambos y que llega a omitir el enunciado de cada uno de los preceptos. Su única pregunta es: ¿Qué se veda en el nono y décimo mandamiento? Menéndez de Luarca estima suficiente tal pregunta y nada añade en este caso.

En cambio, en ediciones posteriores, y también en la de Daniel Llorente que nos sirve de guía, aparecen otras dos preguntas previas a la que Astete escribiera: ¿Cuál es el noveno? y ¿Cuál es el décimo? Desde un punto de vista pedagógico, procedía harer tal inclusión, máxime teniendo en cuenta que en todos los demás mandamientos se exigía su enunciado antes de iniciar toda expłicación ulterior.

A la hora de indagar acerca de la paternidad de quien introdujera ambas preguntas en el texto, nos hemos encontrado con un problema sin resolver, quizá porque el primero que lo hizo estimó que se trataba de una adición sin trascendencia y no dejó constancia de su nombre actuando así en distinta forma de otros correctores que quisieron figurase su aportación.

Se trata sin duda de una adición antigua, puesto que en la edición de 1845 ya tenemos constancia de ella ${ }^{61}$. A pesar de ser tan antigua y de la contundente lógica que evidenciaba su inclusión, no ha estado presente en todas las ediciones que se han ido haciendo del texto de Astete y según unos criterios u otros ha sido incluida ${ }^{62} \mathrm{o}$ excluida ${ }^{63}$.

A partir de las ediciones de Daniel Llorente, o quizá más exactamente

61. Valladolid, 1845 (Imprenta Juan de la Cuesta).

62. Además de las señalada en la nota anterior, incluyen la adición las de Valladolid 1888 (Imprenta F. Santarén); Valladolid 1887 (Imp. de Viuda de Cuesta e Hijos); Valladolid 1895 (Imp. de J. Pastor); Santander 1899 (Imp. «La Propaganda Católica»); Valladolid, 1902 (Imp. de Jorge Montero) y Valladolid 1908 (Imp. Andrés Martín).

63. Excluye la adición las ediciones de Valladolid 1848 (Imp. de J. Pastor); Burgos. 1873 (Imp. de la viuda de Villanueva); Valladolid, 1884 (Imp. de Loonardo Miñón) y Bilbao, 1893 (Imp. del Corazón de Jesús). A este respecto resulta curiosa la edición añadida por Hermenegildo del Río (Vitoria, 1864, 2. a ed.) que no dice nada de los mandamientos noveno y décimo. 
desde las ediciones que hiciera Sanz y Forés desde la proclamación de texto oficial para la provincia eclesiástica de Valladolid, parece que está incluida en todas las ediciones conocidas.

El balance en cuanto a añadiduras en la exposición de los mandamientos nos habla de una sobrecarga al texto salido de las manos de Gaspar Astete, con una notable intención moralizante marcada por el penitenciario de Segovia Gabriel Menéndez. El despojar a Astete de los ropajes que le han envuelto nos lleva a descubrir una doctrina respecto a los mandamiento mucho más sencilla y con seguridad más adaptada a los niños, aunque a todas luces resultara menos completa. Ello nos lleva a replantear una vieja cuestión de pedagogía catequética ¿es preciso presentar «íntegra» la totalidad de la doctrina a los niños, o por el contrario resulta válido hacer una selección en función de su menor capacidad? Astete se inclina por la segunda opción. Menéndez de Luarca también, ya que incluye mucha más materia en su "catecismo mayor». Queda la duda de que haya acertado en la selección hecha para los niños.

\section{Mandamientos de la Iglesia}

La formulación de los mandamientos de la Iglesia no cambia desde el original de Astete hasta la edición de Daniel Llorente que nos marca el camino de esta lectura crítica ${ }^{64}$. En cambio han sido modificadas notablemente las preguntas anejas a los mandamientos de la Iglesia, pues mientras el padre Astete escribió una sola pregunta ${ }^{65}$, en la edición de Daniel Llorente aparecen nada menos que 23 preguntas como explicación de los mandamientos. Son así prácticamente la totalidad de las preguntas las que se han hecho pasar por ser de Astete, cuando en realidad no lo son. Astete se limita a fijarse en la finalidad global de los mandamientos. Sus correctores comentan al detalle cada uno de ellos. Como obedecen a varias manos iremos contemplándolas siguiendo el orden de los preceptos de la Iglesia.

\section{$1 .^{\circ}$ mandamiento de la Iglesia}

El mandamiento no se enuncia, porque se supone la recitación inmediatamente antes, en el lugar que el mismo Astete señalara. Por ello se alude a él solo de pasada.

A él están consagradas tres preguntas brotadas de la pluma de Menéndez

64. Tan sólo una edición hecha en Madrid, sin fecha (Ed. Saturnino Calleja) dice: «El quinto pagar diezmos y primicias a la Iglesia de Dios, o lo que estuviere en su lugar establecido".

65. Astete coloca los mandamientos de la Iglesia a continuación de los mandamientos de Dios, manifestando su carácter complementario, subrayado además por su única pregunta como explicación global a todos ellos: ¿Para qué son estos mandamientos?-_Para mejor guardar los divinos. 
de Luarca. Sus respectivos enunciados son: Y el primero de oír Misa, ¿a quién obliga?; ¿Y cómo la han de oír?, para terminar con $Y$ el que no estando legítimamente impedido, no la oye, o está en ella, o en parte notable sin atención, o se pone en peligro de no oirla, ¿cómo peca. Esta tercera pregunta es un paradigma de casuística, puesto que abarca todos los supuestos en que la asistencia defectuosa a la misa o la no asistencia culposa entrañan el quebrantamiento del mandato de la Iglesia.

A cada una de ellas acompañan las usuales inclusiones pedagógicas brotadas de la intervención de Daniel Llorente.

\section{$2 .^{\circ}$ y $3 .^{\circ}$ mandamientos de la Iglesia}

La obligación de confesar y comulgar son contempladas por Gabriel Menéndez de Luarca en conjunto, dedicando a ellas tres preguntas, de las cuales tan sólo la tercera tiene en cuenta una circunstancia específica de la confesión. He aquí las preguntas de Menéndez de Luarca: $Y$ el segundo y tercero de confesar y comulgar ¿a quién obliga?; $Y$ los que confiesan o comulgan sacrílegamente ¿cumplen con ellos?; y en último lugar $Y$ si uno en peligro de muerte no tiene confesor ¿qué debe hacer? Las cuestiones así formuladas dicen ya de por sí bastante respecto a la preocupación moralizante de su autor. En concreto, la tercera pregunta recuerda incluso en la formulación los «casus conscientiae» presentes en los tratados de moral que han presidido la formación del clero.

\section{4. ${ }^{\circ}$ mandamiento de la Iglesia}

La evolución y los cambios que se han introducido paulatinamente en la disciplina eclesiástica sobre el ayuno y la abstinencia hacen particularmente laborioso dilucidar las aportaciones de cada uno de los correctores de Gaspar Astete, puesto que todos ellos han procurado acomodar preguntas y respuestas a la disciplina vigente en cada momento. A ello se deben una serie de oscuridades que vamos a tratar de precisar.

La edición de Daniel Llorente que nos marca el rumbo incluye un total de 16 preguntas para el cuarto mandamiento sobre el ayuno. Daniel Llorente ha tenido el acierto de ordenar sin mezclarlas las preguntas relativas al ayuno, la abstinencia y la Bula. Pero en ediciones anteriores no están presentadas estas cuestiones con un orden sistemático.

Cinco preguntas son obra sin duda de Gabriel Menéndez, quien las incluye en su texto; son las siguientes: Y el cuarto que es ayunar, ¿a quién obliga?; ¿Y cómo se ha de ayunar?; ¿Y sin faltar a esto, ¿se podrá tomar por la mañana alguna cosa?; ¿ $Y$ a la noche?; para finalizar con $Y$ los que sin legítima causa no ayunan ¿cómo pecan? 
A la primera pregunta que plantea Menéndez de Luarca contesta de la siguiente forma:

"A los que han cumplido veinte y un años». frase:

Daniel llorente matiza la respuesta que resulta expuesta de la siguiente

«El cuarto mandamiento que es ayunar obliga a todos los cristianos que han cumplido veintiún años $y$ no tienen aún cincuenta y nueve».

Aparecen las tres matizaciones por él introducidas: se trata de todos, y no sólo de algunos; por otra parte han de ser cristianos, ya que es una ley positiva de la Iglesia impuesta a sus miembros; finalmente, tiene un tope de edad que finaliza al cumplir los cincuenta y nueve. Además, la correción metodológica. ya usual de introducir la pregunta en la misma respuesta.

La segunda respuesta de Gabriel Menéndez sobre cómo se ha de ayunar dice:

«Absteniéndose uno de manjares prohibidos, y comiendo una sola vez al mediodía».

Tal respuesta figura en los textos editados bajo el impulso de Sanz y Forés, pero Daniel Llorente la corrige bajo esta redacción ${ }^{66}$ :

«Se ha de ayunar abşeniéndose de manjares prohibidos y haciendo al día una sola comida».

La siguiente pregunta que Gabriel Menéndez expresara indagaba si se podría tomar algo por la mañana. También ha persistido la respuesta de Menéndez de Luarca hasta que fue corregida por Daniel Llorente. Menéndez de Luarca dice:

«Con causa, aunque leve, se podrá tomar como una onza».

Daniel Llorente dice así ${ }^{67}$ :

«Por la mañana se puede tomar algún alimento, observando en cuanto a la cantidad y calidad la legítima costumbre».

Sigue la pregunta de Gabriel Menéndez sobre lo que se puede tomar por la noche. Y entre ella y la que se pregunta qué clase de pecado cometen los que no ayunan, Daniel Llorente interpola otra cuestión ${ }^{68}$ :

«¿Se prohíbe mezclar carne y pescado en los días de ayuno? - No está prohibido mezclar carne y pescado los días de ayuno; ni permutar la colación con la comida».

66. La modificación de Daniel Llorente figura en la cuarta edición preparada por él y publicada en Valladolid en 1919.

67. También esta modificación aparece en la edición de 1919 de Daniel Llorente.

68. Menéndez de Luarca habla en su «catecismo menor» de «no mezclar en estos [días] carne y pescado en una misma comida». En la edición de Bilbao, 1893 (Imp. del Corazón de Jesús), 
Además, Gabriel Menéndez de Luarca había escrito en su «catecismo menor» destinado a los niños otras dos cuestiones relativas a esta materia, que han desaparecido al ser desarrolladas posteriormente en otras preguntas que actualizaban la disciplina vigente ${ }^{69}$.

El resto de las preguntas que figuran en la edición de Daniel Llorente de 1957 se pueden repartir con bastante seguridad entre las manos de Sanz y Forés y Daniel Llorente.

Las que provienen de Sanz y Forés, no han llegado hasta nosotros, como figura en los textos más cercanos a Sanz y Forés, sino que han sufrido alteraciones actualizando algunos conceptos ${ }^{70}$.

Otras tres preguntas más completan lo relativo al ayuno y a la abstinencia y obedecen casi con seguridad a la mano de Daniel Llorente. Son éstas: iA quiénes obliga la ley de la abstinencia? ${ }^{71} ;$ ¿Obliga la ley de la abstinencia y la ley del ayuno en los domingos y días de fiesta? y ¿Qué otro privilegio concede la Bula respecto a la abstinencia y ayuno?

Lo relativo al cuarto mandamiento de la Iglesia es un mosaico amalgamado de cuestiones varias, a veces muy minimistas y que han sufrido muchas modificaciones. Desde el escaso núcleo de Menéndez de Luarca, se ha ido adicionando y completando más la cuestión.

Terminamos la exposición referente a los mandamientos de la Iglesia apuntando que ninguno de los correctores, ni Menéndez de Luarca, ni Sanz y Forés, ni Daniel Llorente presentan una sola cuestión o explicación respecto al quinto mandamiento de la Iglesia.

la de Valladolid, 1895 (Imp. de J. Pastor), la de Santander, 1899 (Imp. «La Propaganda Católica»), la de Valladolid, 1902 (Imp. de Jorge Montero) y la de Valladolid 1908 (Imp. de Andrés Martín) hablan del «privilegio llamado Bula de carne; pero los así dispensados no pueden mezclar carne y pescado en una misma comida».

Hay una duda respecto a que su autor sea Daniel Llorente, puesto que en una hoja volante incluida en las ediciones $2 .^{a}$ y $3 .^{\text {a }}$ hechas por él, firmada en Vitoria a 17 de noviembre de 1917 se incluye una pregunta similar. Quizá se trata de una coincidencia, ya que no se corresponden ambas totalmente. Daniel Llorente la presenta incorporada al texto desde la $4 .^{\text {a }}$ edición.

69. Éstas son: "Y los preceptos de no comer carne en días de ayuno, y abstinencia; de no mezclar en éstos carne, y pescado en una misma comida; y de no comer huevos, y lacticinios en la Quaresma (sic) no teniendo Bula, a quiénes obliga? - A todos los que tienen uso de razón». «Y cómo pecan los que no los observan? - Mortalmente todas las veces, que al día faltaren a ellos».

70. Constan en las ediciones de Valladolid apuntadas en la nota 68. Las cuestiones planteadas por Sanz y Forés son: ¿En qué días obliga el precepto de ayuno?; ¿Y qué otra obligación se incluye en este mandamiento?; ¿En qué días obliga esta ley de la abstinencia? ¿ Y cómo pecan los que no observan el prećepto de la abstinencia?; ¿Tenemos en España algún privilegio que nos dispense del ayuno y de la abstinencia?; ¿Qué condiciones se imponen para usar de estos privilegios? y ¿En qué se emplean las limosnas de los que toman la Bula?

71. Esta pregunta está incluida por Daniel Llorente a partir de la cuarta edición de su adaptación. (Valladolid, 1922). Sin embargo, ya se encuentra formulada, aunque no exactamente igual en la hoja volante a que hacíamos alusión en la nota 68 . Se puede suponer igualmente que se trata de una coincidencia al ser modificada la disciplina eclesiástica en este punto. 


\section{Obras de Misericordia}

Las obras de misericordia se nos presentan en el catecismo original de Astete en su doble división tradicional de espirituales y corporales. Están colocadas a continuación de los mandamientos de Dios y de la Iglesia para destacar que son su culminación y complemento.

Astete dedica a su comentario dos preguntas: ¿Por qué se llaman de misericordia? y ¿Cuándo obligan de precepto? Llama la atención que mientras dedica una sola pregunta al comentario de los mandamientos de la Iglesia, consagre dos a las obras de misericordia. De todas formas se ve que la primera pregunta que dedica a ellas es semejante a la que de una manera global aclaraba el sentido que tienen los mandamientos de la Iglesia. En cambio, la segunda pregunta acerca de su obligatoriedad es más necesaria, puesto que los mandamientos dejan más claramente entrever su obligación incluso en su presentación bajo el aspecto de mandatos positivos, mientras que las obras de misericordia aparecen como puras recomendaciones. De ahí la necesidad de precisar que en ocasiones pueden obligar en conciencia.

A las dos preguntas de Astete, Menéndez de Luarca ha añadido otras dos. En la primera se pregunta por la eficacia sobrenatural que se deriva del hecho de poner en práctica las obras de misericordia. Y por estas obras de misericordia y otras buenas que ejecuta el cristiano, ya sean de precepto, ya de devoción ¿qué consigue? Como en la respuesta a esta pregunta señala la condición de que hay que estar en gracia de Dios, la pregunta siguiente se centra en esta cuestión y en la eficacia de las obras buenas hechas en pecado.

Ambas cuestiones están a todas luces fuera de lugar en un catecismo destinado a niños. Menéndez de Luarca las plantea y amplía, lógicamente, en su "catecismo mayor» 72 .

Terminemos esta reflexión sobre la tercera parte del catecismo de Astete destinada a «lo que se ha de obrar». De las 78 preguntas que aparecen en la edición de Daniel Llorente que ha ido recogiendo todas las adiciones anteriores, tan sólo 28 cuestiones han brotado de la pluma de Gaspar Astete. Casi constituyen el doble las preguntas añadidas a esta tercera parte, desfigurando notablemente el escrito de Astete e incorporando un tinte de matiz moralista en cuanto al perfeccionamiento en la expresión de cada una de las posibles transgresiones a los mandatos de Dios o de la Iglesia.

El afán perfeccionista ha querido transformar el catecismo en un breve tratado de moral. Y mientras la primera parte sobre el credo o la segunda sobre la oración no se prestaban tanto a ello, lo relativo a los mandamientos, y más aún la aclaración y explicitación de unas leyes positivas de la Iglesia, como ocurre con la del ayuno y abstinencia ocupan gran número de cuestiones

72. Menéndez de Luarca, l.c., p. 123-127. 
desplazando el auténtico interés que ha de estar presente en la confección de un catecismo.

En ese sentido hay que reconocer que el $\mathrm{P}$. Astete está más cerca de una presentación sintética de lo fundamental de la fe a los niños. Las ampliaciones posteriores se pueden considerar necesarias o accesorias desde distintos puntos de vista. Pero en muchos casos hay que convenir en su evidente desproporción para la mentalidad infantil.

$\mathrm{Y}$ desde luego la honradez exige no hacer pasar como formulaciones de Astete aquellas en las cuales ni siquiera él pensó presentar a los niños.

\section{G. Cuarta parte de la doctrina cristiana}

El P. Astete nos dice que en ella se trata de «los sacramentos que se han de recibir». Al contrario que los mandamientos de Dios que estaban enunciados en la introducción de la Doctrina Cristiana, los sacramentos no figuran en ella, sino que están presentados al inicio de la cuarta parte. Al recitado de los sacramentos siguen unas cuestiones de índole general que hay que tener presentes para todo el «tratado» de los sacramentos. Las que son originales de Astete son: ¿Qué cosa son los Sacramentos?; ¿Qué cosa es gracia?; ¿Qué virtudes dan los sacramentos juntamente con la gracia? ${ }^{73}$; ¿Cuáles son?; ¿Qué cosa es Fe? ${ }^{74}$; ¿Qué cosa es Esperanza? y ¿Qué cosa es Caridad? A tales cuestiones Gabriel Menéndez introduce otras preguntas que no son sustanciales, sino que, como suele ser habitual en él, se plantean en un terreno para el cual los niños están incapacitados. Sus preguntas son ¿Cómo se llama esa gracia? (después de hablar de qué es gracia); Y hay algún otro género de gracia además de ésta?; ¿Y éstas qué son?, preguntas estas últimas que se refieren a las gracias actuales para distinguirlas de la gracia santificante. La distinción no es asequible a los niños.

A continuación inicia el recorrido por los sacramentos, que vamos a ir diferenciando por llevar un poco de orden al contemplar cada uno.

\section{El bautismo}

Sobre el primer sacramento, Astete sólo ha hecho dos preguntas: ¿Para qué fue instituido el Sacramento del Bautismo? y ¿Qué es pecado original? Otras dos cuestiones han sido incorporadas después por intervención de Me-

73. La respuesta permite a las virtudes teologales, como se deduce de la formulación de las preguntas siguientes. En cambio, después de haber terminado con los sacramentos, Astete volverá a considerar las virtudes teologales, además de las cardinales.

74. Ya antes, al comienzo del credo había hecho la misma pregunta contestando que fe es "creer lo que no vimos». Ahora, quizá por considerarlo desde el ángulo de la virtud teologal, responde que es «creer lo que no vimos porque Dios lo ha revelado». Choca que la primera vez, hablando del credo, no remita a la autoridad de Dios revelador como hace ahora. 
néndez de Luarca, quien pregunta por el ministro extraordinario del bautismo y la manera de realizarlo: $Y$ en caso de necesidad ¿quién puede bautizar?; ¿ $Y$ cómo lo ha de ejecutar?

En todas las preguntas, excepto la última que refleja íntegramente la respuesta ofrecida por Menéndez de Luarca, Daniel Llorente ha introducido, como es usual en él, la innovación metodológica de hacer que también esté presente la pregunta en la respuesta.

\section{La confirmación}

La enseñanza sobre la confirmación es aún más escueta, puesto que Astete ha planteado una sola pregunta: ¿Para qué es el Sacramento de la Confirmación? Con ello estima que es suficiente. El acento moralista de Menéndez de Luarca vuelve a salir en las dos preguntas añadidas: $Y$ el que tiene uso de razón y recibe este sacramento en pecado mortal ¿peca? y Pues ¿qué ha de hacer para no pecar recibiéndole?

Las adiciones de Daniel Llorente superan en este caso el aspecto metodológico, puesto que modifica la respuesta que Gabriel Menéndez da a su segunda pregunta. La respuesta de Menéndez dice así:

«Disponerse antes, haciendo una buena confesión».

Daniel Llorente matiza aún más ofreciendo esta nueva respuesta:

«Para no pecar recibiéndole ha de disponerse antes, confesándose o haciendo un acto de perfecta contricion».

El estimar inexacta la frase de Gabriel Menéndez de Luarca le hace añadir el punto de que también por la perfecta contrición puede quedar uno en condiciones de recibir el sacramento de la confirmación.

\section{La penitencia}

Como ya es habitual, Astete escribió sobre el sacramento de la penitencia mucho menos de lo que después se ha hecho pasar por suyo. Tan sólo once preguntas ha escrito sobre la penitencia, al menos como se nos presenta en la edición de Daniel Llorente. En realidad había escrito doce, pero Daniel Llorente funde dos preguntas en una para simplificar. Las que son originales de Gaspar Astete son: ¿Para qué es el Sacramento de la Penitencia?; ¿Qué pecados son éstos?; ¿Qué es pecado mortal?; ¿Por qué se llama mortal?; ¿Qué partes tiene la penitencia para quitar el pecado mortal? ${ }^{75} ;$ ¿Y es menester siempre que uno cae en pecado mortal confesarse luego para que se le perdo-

75. La respuesta concisa de Astete es: Tres. Luego sigue otra pregunta: ¿Cuáles son? -Contrición de corazón, confesión de boca y satisfacción de obra. Llorente las funde en una sola. 
ne?; ¿Pues qué hemos de hacer?; ¿Qué cosa es pecado venial?; ¿Por cuántas cosas se le perdona?; ¿Cuáles son?

Se deduce que el padre Astete ha ceñido su explicación al núcleo esencial de cosas que hay que presentar en torno al sacramento de la penitencia. El moralista Gabriel Menéndez de Luarca no podía desaprovechar una ocasión para matizar y corregir abundantemente lo que Astete había ofrecido en síntesis. De nuevo duplica el número de las preguntas de Astete añadiendo 25 preguntas más que perfeccionen la anterior exposición incompleta.

La primera cuestión de Menéndez de Luarca es: ¿ $Y$ cuándo recibimos el Sacramento de la Penitencia? Siguen las preguntas de Astete fundidas en una por Daniel Llorente y que se refieren a las partes necesarias para el sacramento: contrición de corazón, confesión de boca y satisfacción de obra. No contento con tal precisión, Menéndez de Luarca va más lejos que el concilio de Trento ${ }^{76} \mathrm{y}$ formula la pregunta: $Y$ en estas tres cosas precisas en el que quiere recibir este Sacramento, ¿se incluyen algunas otras?

Sigue otra pregunta de Menéndez en la que incluye en pie de igualdad las partes esenciales, más otras dos que, sin serlo, son de sentido común, pero que nunca se han presentado como requisitos previos para la confesión: el examen de conciencia y el propósito de la enmienda: ¿Cuántas cosas son necesarias para recibir el sacramento de la penitencia o confesarse uno bien?

A continuación Gabriel Menéndez explaya en una serie de preguntas las tres partes esenciales más las dos accesorias, que se han presentado en igualdad de condiciones ${ }^{77}$. Al examen de conciencia dedica esta pregunta: ¿Qué es examen de conciencia?

A la contrición dedica una serie de preguntas: ¿De cuántas maneras es la contrición de corazón?; ¿Qué es contrición perfecta?; ¿Y qué es atrición?; ¿Y cuál de estos dolores es el mejor?; ¿Y por qué?; Y para confesarse uno bien, ¿basta el dolor de atrición o se requiere el de perfecta contrición?; ¿Y cuándo se ha de tener el dolor? Sólo por el enunciado de las preguntas vemos una ex-

76. En la sesión XIV, cap. 3 dice: «Sunt autem quasi materiae huius sacramenti ipsius paenitentis actus, nempe contritio, confessio et satisfactio. Qui quatenus in paenitente ad integritatem sacramenti, ad plenamque et perfectam peccatorum remissionem ex Dei institutione requiruntur, hac ratione paenitentiae partes dicuntur». En el canon respectivo (n. $\left.{ }^{\circ} 4\right)$ vuelve a afirmar que «ad integram et perfectam peccatorum remissionem requiti tres actus in paenitente quasi materiam sacramenti paenitentiae, videlicet contritionem, confessionem et satisfactionem, quae tres paenitentiae parte dicuntur» (Denzinger-Schönmetzer, ed. $32 .^{a}$, n. $^{\circ} 1673$ y 1704 respectivamente).

77. Otro tanto le había ocurrido al texto de Ripalda, que de una expresión de las tres partes necesarias, se vio ampliado a las cinco habituales.

No todos los catecismos hablan de cinco partes; algunos hablan de tres, aunque una explicación amplia haga ver que se incluyen el examen y el propósito. Ver Catecismo de Trento, Parte II, cap. V, n. ${ }^{\circ} 21$ y ss. 
posición detallada y minuciosa que queda aún más desmenuzada en las respuestas correspondientes.

Al propósito dedica una sola pregunta: ¿Qué cosa es propósito? Después de interrogar sobre ¿Qué es confesión de boca?, formula otra pregunta que sólo en su enunciado es un verdadero tratado de casuística previendo todas las posibilidades de portarse mal: Y el que calla por vergüenza algún pecado mortal, o confiesa alguno grave que no ha cometido, o hace su confesión sin dolor, o sin propósito, o sin ánimo de cumplir la penitencia, ¿se confiesa bien? Vuelve de nuevo a la cuestión conjunta del dolor y del propósito en dos preguntas más: ¿Y quiénes pueden creer no haber tenido dolor ni propósito en sus confesiones? ¿Y para excitarse uno a formar dolor y propósito verdadero, ¿qué le será conveniente hacer?

Plantea además tres cuestiones relativas a la satisfacción: ¿Qué es satisfacción de obra?; ¿ Y cómo peca el que no cumple la penitencia o dilata mucho tiempo el cumplirla?; ¿Y podemos satisfacer a Dios por las penas temporales más que con la penitencia que se nos impone?

Como una cuña, Menéndez de Luarca introduce aquí la cuestión de las indulgencias, que Astete no había tocado, ni tampoco el catecismo de Trento. Desde luego que no es una cuestión que importe mucho a los niños a los que está dirigido el catecismo, así como es muy discutible el tratar en este preciso lugar de ello ${ }^{78}$. Las preguntas sobre el tema son: ¿Qué cosa son las indulgencias?; ¿Y como se han de ganar?; Y a los que por no satisfacer en esta vida van al Purgatorio, ¿nosotros los podemos socorrer y ayudar?

Las aportaciones de Gabriel Menéndez terminan con tres preguntas. La primera de ellas está añadida a la novena cosa que perdona los pecados veniales, pero extensiva a todas las demás; ahí se dice que «por golpes de pecho pidiendo a Dios perdón». Gabriel Menéndez pregunta: ¿Por qué añadís: pidiendo a Dios perdón? Las dos últimas adiciones de Menéndez dicen también relación con los pecados veniales: ¿Y estamos obligados a confesar los pecados veniales?; Y al que después de la última confesión tiene sólo veniales, ¿qué le será conveniente hacer para asegurar el dolor y propósito?

La extensa aportación de Gabriẹl Menéndez en la materia del sacramento de la penitencia es un síntoma claro de que desde su condición de penitenciario buscar un perfeccionamiento a la hora de la confesión, en el que no se incurra en defectos de forma. Para ello añade pregunta tras pregunta hasta dejar en penumbra el texto original de Astete e infundiendo al catecismo un tono moralizante inequívoco.

La aportación de Daniel Llorente en relación al sacramento de la peniten-

78. En su «catecismo mayor», Menéndez de Luarca introduce también la doctrina de las indulgencias en el mismo lugar a continuación de la satisfacción (l.c., p. 164-166). 
cia está ceñida en la generalidad de los casos a la aportación metodológica a que nos titne habituados. Pero hay un momento en que substituye una expresión, una palabra de Menéndez de Luarca para afirmạr con más rotundidad la idea que pretende quede clara. Se trata de la pregunte que Menéndez de Luarca formula sobre los defectos en que se puede incurrir al hacer la confesión: $Y$ el que calla por vergüenza algún pecado mortal... (ver p. 50). A ella contesta diciendo que quien se confiesa así "comete un gran sacrilegio»... La palabra «gran» no le convence a Daniel Llorente por cuanto no está incluida en la terminología usal que distingue los pecados entre graves y leves. Por eso la substituye y la frase sale así de sus manos: "comete un grave sacrilegio...»

\section{La comunión}

Pasemos al sacramento de la Eucaristía, que es incluido en la enumeración de los sacramentos que Astete hace con el término restrictivo de «comunión». La trascendencia de usar tal palabra es evidente, porque todas las explicaciones incluidas en el texto (las de Astete y las adiciones posteriores) consideran la Eucaristía no tanto desde el punto de vista de la celebración, cuanto de la apropiación que el cristiano hace de ella a través de la comunión ${ }^{79}$.

Con tal precedente vamos a abordar la diferenciación de cuestiones netas de Astete y las añadiduras posteriores. De las 14 preguntas dedicadas al tema, sólo dos han salido de manos de Astete. Ya nos tiene acostumbrados a ceñirse a lo esencial; ¿Para qué es el Santísimo Sacramento de la Comunion? y ¿Qué recibís en el Santísimo Sacramento de la Comunión? No dice más sobre este sacramento porque estima que con lo expuesto es suficiente. Hay que resaltar, sin embargo, la diferencia que establece respecto a los demás sacramentos, puesto que habla del «Santísimo Sacramento de la Comunión», cosa que no hace en ninguno de los demás.

Astete habla de que hay que recibir la comunión «dignamente». Apoyándose en esta expresión Menéndez de Luarca introduce su primera pregunta: ¿Por qué decís dignamente?, lo que le da pie a distinguir las disposiciones necesarias por parte del alma y del cuerpo. A la primera aluden estas preguntas; Pues, ¿qué disposición es necesaria por parte del alma?; Y el que cayó en pecado mortal ¿cómo se ha de disponer para comulgar?; $Y$ el que después de confesado se acuerda de algún pecado grave ¿qué debe hacer? Esta tercera cuestión debería estar propiamente dentro de las que se refieren a la penitencia, puesto que no se trata de una conducta directamente vinculada con la comunión, sino que atañe a la tranquilidad del penitente tanto si comulga como

79: J.J. Rodriguez Medina afirma en Pastoral y catequesis de la Eucaristia, (Salamanca 1966, p. 110: «Neta separación entre misa y comunión existe en los clásicos catecismos de Astete y Ripalda». 
si no lo hace. Sigue una pregunta que mira a la disposición corporal: $Y$ de parte del cuerpo, ¿qué disposición se requiere? ${ }^{80}$.

A continuación de esta pregunta viene la segunda que formulara Astete que habla de que en la comunión se recibe «a Cristo, verdadero Dios y hombre, que está verdaderamente en el Santísimo Sacramento del altar». Ello da pie a Menéndez de Luarca para plantear una serie de interrogantes sobre la presencia de Cristo en la eucaristía: Según eso, ¿quién está en la hostia después de la consagración?; ¿Y en el cáliz?; según eso, ¿todo Jesucristo está en la hostia y en el cáliz?; Y después de la consagración, ¿hay en la hostia pan o en el cáliz vino?; Y si se parte la hostia o divide lo que hay en el cáliz, ¿se parte o divide a Jesucristo? Cuestiones todas ellas que tratan de precisar más y más la doctrina de la Eucaristía. Alguna linda con lo ridículo, aunque haya que reconocer que es una vacilación que se puede presentar a la mentalidad excesivamente simplista de los niños.

Las dos últimas preguntas de Menéndez de Luarca tienen una carga de preocupación por la eficacia del sacramento tanto en los que lo reciben bien como en los que lo reciben mal: Y el que llega a la Comunión sin las disposiciones dichas, ¿recibe también a Jesucristo?; Y aquellos a quienes aprovecha, además de lo dicho, ¿qué les será conveniente hacer para que consigan mayores frutos?

Hasta aquí la aportación de Gabriel Menéndez. La de Sanz y Forés está presente modificando una respuesta de Gabriel Menéndez. Daniel Llorente interviene a su vez simplificando la respuesta de Sanz y Forés. Se trata de la respuesta a la pregunta sobre lo que debe hacer quien después de haberse confesado recuerda que tiene algún pecado grave. Gabriel Menéndez responde escuetamente:

«Confesarlo antes»

Tal respuesta se presta al equívoco (confesarlo cuanto antes, después de haber comulgado o verse en la precisión de confesarlo necesariamente antes de comulgar). Por ello Sanz y Forés responde así:

"Confesarlo antes si fácilmente puede hacerlo, y si no en la primera confesión que haga después».

80. La respuesta de Menéndez de Luarca habla de no tomar nada «desde las doce de la noche antecedente». A persistido hasta que en la edición $23 .^{\text {a }}$ de Daniel Llorente (1953) se incluye en la respuesta la frase «Pero puede tomarse agua» y en nota a pie de página dice: «en ciertos casos de enfermedad o grave incomodidad, a juicio del confesor puede tomarse algo a modo de bebida y también medicinas». Así figura en las tres variantes de la edición $24 .^{a}$ (1954, 1955 y 1956). En la edición de 1957 habla de no comer ni beber desde «el tiempo señalado por la Iglesia», y la nota de pie de página: «Desde tres horas antes de comulgar no pueden tomarse alimentos sólidos, ni bebidas que contengan alcohol. Desde una hora se prohíben otros alimentos y bebidas. Los enfermos pueden tomar a cualquier hora bebidas no alcohólicas y medicinas». Semejantes modificaciones constan en las últimas ediciones de Burgos, sin fecha (Hijos de Santiago Rodríguez) en Burgos. 
Daniel Llorente no está conforme con la redacción, y además de introducir la usual corrección metodológica suprime una frase de Sanz y Forés estimando que no es necesario. Su respuesta queda redactada como sigue:

«El que después de confesado se acuerda de algún pecado grave debe confesarlo en la primera confesión que haga después».

Volvemos a ver desbordada ampliamente la doctrina sintética que escribiera Gaspar Astete. En lo relativo a la Eucaristía sus preguntas han sido sextuplicadas. No es válido atribuir a Astete lo que no es de Astete.

\section{La extremaunción}

Denominada con tal palabra en lugar de la que sugiere el nuevo ritual: Unción de enfermos. Sobre ella el P. Astete ha escrito las dos primeras preguntas empalmadas entre sí. La primera es ¿Para qué es el sacramento de la Extremaunción? La respuesta que da es bien sencilla: Para tres cosas. Por tanto la pregunta siguiente es obligada: ¿Cuáles son? En la correspondiente respuesta explica el triple efecto del sacramento sobre el enfermo en lo que hace a la regeneración espiritual, a superar las dificultades propias de la enfermedad y a la eventual salud corporal.

Menéndez de Luarca apostilla dos cuestiones más sobre la obligación que existe de recibir el sacramento y sobre las condiciones en que ha de hacerse: i $Y$ tienen obligación de recibir este sacramento los que llegan al uso de la razón y se hallaran enfermos de peligro? y ¿Qué ha de hacer el que se halla en pecado mortal para recibirlo dignamente?

Las respuestas de Gabriel Menéndez de Luarca a estas dos preguntas han sido modificadas por Daniel Llorente. A la primera Menéndez de Luarca ofrece esta respuesta:

«Si, Padre, pecan mortalmente si pudiendo no lo reciben o lo hacen en pecado mortal».

Daniel Llorente, en cambio dice así:

"Los que han llegado al uso de la razón y se hallan enfermos de peligro deben recibir este Sacramento y pecan si pudiendo no lo reciben»

Llorente suprime la frase «o lo hacen en pecado mortal» porque la doctrina en ella contenida discrepa de la que ha mantenido la Iglesia sobre este sacramento ${ }^{81}$.

81. Ya en el concilio Tîncinense (celebrado en Pavía) del año 850 se había enseñado a propósito de la unción: «Magnun sane ac valde appetendum mysterium, per quod, si fideliter poscitur, et peccata remittuntur, et consequenter corporalis salus restituitur...». El concilio de Trento había dicho a este respecto: «Res porro et effectus huius sacramenti illis verbis explicatur: Et oratio fidei salvabit infirmum, et alleviavit eum Dominus; et, si in peccatis sit, dimittentur ei. Res etenim haec gratia est Spiritus Sancti, cuius unctio delicta, si quae sint adhuc expianda, ac peccati re- 
A la segunda respuesta de Gabriel Menéndez, también introduce una modificación Daniel Llorente. Véamos la respuesta de Gabriel Menéndez:

«Confesarse antes, o no pudiendo executarlo hacer un acto de perfecta contrición».

Llorente deja así la respuesta anterior:

«El que se halla en pecado mortal ha de confesarse antes o hacer un acto de perfecta contrición, o no pudiendo, a lo menos un acto de atrición».

Suprimo lo de «o no pudiendo executarlo» y añade a partir de la $11 .^{a}$ edición de su adaptación ${ }^{82}$ la concesión del acto de atrición para quien no puede hacer el de contrición.

\section{El orden}

El padre Astete ha puesto en su texto de catecismo una sola pregunta: ¿Para qué es el Sacramento del Orden?

Menéndez de Luarca se interesa en esta ocasión por un asunto que en nada atañe al conocimiento de la doctrina cristiana, sino a la práctica usual de la sociedad tradicionalmente cristiana: $Y$ los ministros de la Iglesia, particularmente los sacerdotes, ¿deben ser respetados y venerados con especialidad? Cabe suponer que se fije especialmente en los sacerdotes porque se encuentran en un contacto más directo con el pueblo que los obispos o los diáconos.

\section{El matrimonio}

También para el matrimonio ha puesto Gaspar Astete una pregunta: ¿Para qué es el Sacramento del Matrimonio?

Al igual que sucedía con la unción de enfermos, Menéndez de Luarca pone el acento en su aportación en torno a las condiciones necesarias para recibir el sacramento, asunto que ni siquiera ha planteado Astete. Por ello sus preguntas vienen expresadas con las siguientes palabras: ¿ $Y$ es necesario para recibir dignamente este sacramento estar los que se casan en gracia de Dios? $Y$ los que no se hallan en gracia de Dios, ¿cómo se han de disponer para recibirlo?

liquias abstergit et aegroti animam alleviat et confirmat...» (Ses. XIV, De Sacramento extremae unctionis, cap. 2). El canon correspondiente afirma: «Si quis dixerit, sacram infirmorum unctionem non conferre gratiam, nec remittere peccata, nec alleviare infirmos, sed iam cessasse, quasi olim tantum fuerit gratia curationum: anatema sit» (Denzinger-Schönmetzer, ed. $32 .^{\mathrm{a}}, \mathrm{n} .^{\circ}$ 620,1696 y 1717 respectivamente).

82. La edición $11 .^{a}$ es de 1933. A partir de ella consta la edición a que nos referimos, pero puede ser que conste también en la edición $10{ }^{a}$, que no hemos conseguido localizar, y que tiene que datar de 1931 ó 1932. 
Con ello termina la parte relativa a los sacramentos. El balance, en cuanto al número de adiciones que se han ido incorporando al texto primitivo es alarmante, puesto que son más las añadiduras que las preguntas originales. De 76 cuestiones que integran la cuarta parte en la edición de Daniel Llorente sobre la que trabajamos como guía, solamente 27 son atribuibles al P. Astete mientras que otras 49 han sido obra de Gabriel Menéndez de Luarca. Constan además otras adiciones o supresiones en las respuestas correspondientes, que ya hemos señalado. Inevitablemente el centro de gravedad del «tratado» de los sacramentos se desliza hacia una moral sacramental, con una gran cantidad de preguntas relativas a las condiciones en que se ha de recibir un sacramento determinado y cada uno de los pasos que ha de dar el sujeto para una adecuada recepción.

Menéndez de Luarca imprimió un cuño indeleble, transmitiéndonos una visión de los sacramentos que no sólo no responde a la actual visión, sino que tampoco respeta la presentación sencilla y esquemática que Astete había estimado como suficiente.

\section{H. Otras formulaciones incluidas en la doctrina cristiana}

Terminados los sacramentos y su exposición, el P. Astete empalma sin hacer distinción ni marcar diferencia con otras formulaciones que de alguna manera se pueden considerar como vinculadas aún con el núcleo de la doctrina cristiana. Todas ellas tienen la particularidad de utilizar prodecimiento mnemotécnico consistente en describirlas agrupándolas en series. No se nos habla aisladamente de la justicia, por ceñirnos a un ejemplo, sino que se nos presenta dentro de una serie, la de las virtudes cardinales y siempre unida a las otras tres virtudes que integran la serie. Cada una de las series precisa en su enunciado el número de miembros que la integran, y se trata de memorizar y retener todos los nombres ${ }^{83}$. Tan sólo para algunas de estas series han sido adjuntadas algunas preguntas aclaratorias, mientras que otras se limitan a la mera enumeración, sin que la configuración del texto del catecismo proporcione ninguna explicación ulterior.

Vayamos viendo-por separado cada una de ellas.

\section{Los pecados capitales}

La primera serie la constituyen los pecados capitales que vienen seguidos de diez preguntas originales todas ellas de Astete. Hay una pregunta destinada

83. El procedimiento de agrupar todas las series iguales en números para el estudio del catecismo había sido usado por Daniel Llorente con el nombre «Cosas de uno, cosas de dos, cosas de tres, etc.". Se trataba de que los chicos que ya conocían el catecismo lo repasaran recordando todas las series iguales. Por ejemplo: cosas de siete: Obras de misericordia espirituales, corporales, pecados capitales, virtudes contrarias, etc. Ver Revista Catequística, 5 (1914), p. 327-330: «Exámenes de religión»; e Id. 16 (1925), p. 190: «Cosas de tres». 
a precisar el sentido de cada uno de los pecados. Previamente van tres preguntas de carácter común a todos estos pecados: ¿Por qué llamáis pecados capitales a los siete que comunmente se llaman mortales?; ¿Cuándo son mortales? y ¿Cuándo son contra la caridad?

\section{Virtudes contrarias a ellos}

Tanto en Astete como en las ediciones posteriores se ha reproducido la lista de las virtudes contrarias a cada uno de los pecados capitales, sin que se halla producido modificación alguna.

\section{Los enemigos del alma}

La enunciación de los enemigos del alma surge de la pluma del P. Gaspar Astete seguida de tres preguntas con una visión muy utilitaria, y formuladas todas ellas con idénticas palabras: ¿Cómo se huye del mundo? (y del demonio y de la carne). Gabriel Menéndez ha interpolado en cada una de estas preguntas un inciso dejándolas así: ¿Cómo se vence $y$ huye del mundo? Además ha colocado previas a las tres preguntas de Astete otras tres que aclaran: ¿Quién es el mundo?; ¿Quién es el demonio?; ¿Quién es la carne? De esta manera completa una formulación - la realizada por Astete - en la que las palabras «mundo» $\mathrm{y}$ «carne» especialmente, pueden no ser entendidas por los niños.

\section{Las virtudes teologales}

Gaspar Astete se limita a enunciarlas. En cambio Menéndez de Luarca, las completa con una pregunta: ¿Cómo no faltaremos a la obligación que tenemos de hacer actos de estas virtudes? Resulta llamativo que sin haber hablado previamente de la obligación de ejercerlas, la dé por supuesta y se pregunta por la manera de cumplir con dicha obligación.

\section{Las virtudes cardinales}

Las cuatro virtudes cardinales son presentadas por Astete y por sus sucesivos correctores en una enumeración escueta y sin ninguna otra clase de explicación.

\section{Los sentidos corporales}

En este caso, en cambio, Astete no se ha limitado a presentar la lista de los sentidos, sino que los acompaña de una pregunta general sobre la finalidad de tales sentidos: ¿Para qué nos dio Dios los sentidos y todos los demás miembros? La pregunta ha sido respetada por las sucesivas manos, haciendo caso omiso de la adaptación metodológica de Daniel Llorente de incluir la pregunta en la respuesta, como característica de sus ediciones. 


\section{Las potencias del alma}

Además de la enumeración, el P. Astete no se conforma en este caso en repetir lo mismo que hizo con los sentidos corporales, planteando una cuestión global sobre la finalidad de todos ellos. Pregunta en singular para cada una de las potencias del alma, aunque repitiendo el enunciado: ¿Para qué nos dio Dios la memoria? (y el entendimiento y la voluntad). A las tres preguntas así originadas añade Menéndez de Luarca una cuestión que engloba a las tres, trascendiéndolas: ¿Y qué cosa es nuestra alma, cuyas son estas potencias? Parece que la cuestión se la había olvidado o pasado por alto al $P$. Astete. Gabriel Menéndez nos lo recuerda.

\section{Dones y frutos del Espíritu Santo}

A continuación viene la doble enumeración escueta, brotada también de la pluma de Gaspar Astete, de los siete dones y los doce frutos del Espíritu Santo. A pesar de que bien exigirían una aclaración, al menos en cuanto a la terminología empleada, ninguno de los correctores de Astete ha considerado que valía la pena el esfuerzo y ha continuado la enumeración pura y lisa.

\section{Las bienaventuranzas}

También han brotado directamente de Astete con la formulación y las palabras que constan en el catecismo. El mismo Astete ha estimado que valía la pena hacer una explicación y las acompaña de doce preguntas: una dedicada a cada una de las ocho bienaventuranzas; además, otras cuatro: una para preguntar ¿Cómo poseerán la tierra? (los mansos), y otras tres de carácter general. Al principio de la explicación inserta ésta: ¿Qué hemos dicho ahora? y $¿ Q u e ́$ cosas son estas ocho bienaventuranzas?; al final incluye la siguiente pregunta: ¿Por qué se llaman bienaventuranzas?

En la pregunta ¿Quiénes son los pobres?, Gabriel Menéndez ha añadido una apostilla a la respuesta que ofrece Astete. Éste dice que lo son «los que no quieren honras ni riquezas aun moderadas». Menéndez de Luarca intercala: «Los que no quieren, a lo menos con el afecto, honras ni riquezas aun moderadas».

Como la respuesta a la pregunta anterior conclusiva de las bienaventuranzas habla de la esperanza de la otra vida, el P. Gaspar Astete pone fin a su catecismo con una brevísima reflexión: El Señor nos lleve a todos allá. Amén.

\section{Los novísimos}

Menéndez de Luarca no se queda satisfecho con que termine así el catecismo, pues considera que es preciso suplir la omisión de los novísimos. El, pues, los introduce en forma de cinco preguntas: ¿Cuántos son los 
Novísimos? ${ }^{84}$; ¿Qué es Gloria?; Y para librarnos de éste y conseguir aquélla, ¿qué hemos de ejecutar?; ¿Y hay algunos medios conducentes para que con mayor facilidad podamos guardar éstos, y preservarnos de faltar a ellos?; y ¿Cuáles son?

Como la última pregunta que había escrito señalaba varios medios útiles para observar los mandamientos, a continuación de las explicaciones de los novísimos, y antes de la reflexión final que Astete había presentado, Menéndez de Luarca nos ofrece una más larga, más ampulosa, que textualmente es: Bien decís, porque la elección de un buen confesor, como dice San Francisco de Sales, es la advertencia de las advertencias. Hacedlo vosotros así, pues éste será como un ángel que os guiará, proponiéndoos estos y otros medios, para que caminéis por la senda de los mandamientos y lleguéis a ver a Dios en la Gloria, que es el fin para que fuimos criados ${ }^{85}$.

\section{APÉNDICES}

Resulta difícil distinguir con seguridad entre los apéndices y oraciones que se insertan en el catecismo los que el P. Astete integró en su texto original y los que no lo fueron. Así como para las demás frases hemos señalado ya el cuidado con que precisa Gabriel Menéndez en sus dos catecismos lo original de Astete y las adiciones hechas por él ${ }^{86}$, en los apéndices resulta mayor el margen de duda. El único dato por el que nos podemos mover con cierta seguridad es la edición de Valladolid, 1825, ya citada, en la que nos presenta el Astete sin adiciones.

Suponiendo la misma distinción, podríamos afirmar que introduce en su texto la Confesión (Yo pecador); el Acto de contrición; la Letanía de Nuestra Señora; El modo de ayudar a misa y la Oración del Santo Sudario. Termina dicho texto con los versos sobradamente repetidos en casi todas las ediciones al comienzo y como pie de la reproducción de un crucifijo:

Dulce Jesús de mi vida

que en la cruz estáis por mí,

84. Daniel Llorente modifica la pregunta cambiándola en ¿Cuáles son los Novísimos?

85. En su "catecismo mayor» (l.c., p. 225) Menéndez de Luarca introduce una reflexión con el consejo de leer el libro de Gerónimo (sic) Dutari: Vida Christiana, o Práctica fácil de entablarla con medios, y verdades fundamentales contra ignorancias o descuidos comunes», que inserta a continuación de su catecismo y constituye la segunda parte del mismo.

Si aceptamos la fecha de 1592 o anterior para la confección del texto por parte de Astete, difícilmente podría recomendar un consejo de San Francisco de Sales, ordenado de presbítero el 18 de octubre de 1593, y por supuesto no canonizado. Fue canonizado por Alejandro VII el 19 de abril de 1665 . Este solo dato tendría que haber puesto en guardia a quienes pretenden ofrecer el texto «original» de Astete acerca de la autenticidad de las frases que se le atribuían.

86. Ver nota 21 donde se recogen otras ediciones que distinguen la parte de Astete de las añadiduras de Gabriel Menéndez. 
en la vida y en la muerte

Señor, acordáos de mí.

Si hemos descrito los apéndices supuestamente escritos por Astete, vamos a describir también el que añade Menéndez de Luarca, en el supuesto de que no se haya ido incorporando en ediciones aparecidas entre la fecha en que escribiera el P. Astete su catecismo, y la fecha en que Gabriel Menéndez publicara su "catecismo menor». El único atribuible a Menéndez sería: Oración breve para ofrecer por la mañana, a honra, y gloria de Dios todas las obras del dia ${ }^{87}$.

En la edición 25. ${ }^{\mathrm{a}}$ de Daniel Llorente sobre la cual hemos hecho esta lectura crítica hay además otros cuatro apéndices. Para dos (los misterios del Rosario a la Santísima Virgen y la Oración a San José) no resulta fácil precisar el momento de su inclusión en el catecismo, por faltar de localizar muchísimas ediciones intermedias.

Los Actos de fe, esperanza y caridad, podrían ser debidos a la mano de Sanz y Forés, pues en el concilio provincial de Valladolid de 1887, por él presidido, se dice a propósito del catecismo:

«Peropportunum etiam erit formulam actuum fidei, spei et charitatis unam eamdemque esse in Dioecesibus nostris et eam quae ad calcem praedicti Catechismi apposita invenitur» ${ }^{88}$.

El otro apéndice titulado «Máximas de Nuestro Señor Jesucristo tomadas del Santo Evangelio» obedecen a la mano de Daniel Llorente, quien a partir de la edición $15 .^{a}$ del texto por él arreglada las introduce para substituir unos apéndices también muy usuales titulados «Máximas morales» y «La salve en verso». La razón que nos da para tal introducción nos viene confirmada en el prólogo que hace a «El libro sobre la Misa», de Daniel Goens, donde escribe:

«En religión somos partidarios de que basta con el texto de Catecismo (aun éste, si fuera preciso, con restricciones) y algunas máximas de la Sagrada Escritura, principalmente del Evangelio».

\section{VALORACIÓN CRÍTICA DE LAS DISTINTAS APORTACIONES}

Son suficientemente conocidas las connotaciones que se han señalado en los catecismos postridentinos, y especialmente en los surgidos como réplica a

87. En su «catecismo mayor», Menéndez de Luarca introduce estos apéndices: Motivos poderosos para resolverse el Christiano a practicar con fervor los medios conducentes para entablar una Vida Christiana, Meditaciones de la Pasión de Nuestro Señor Jesu-Christo, Exercicio sobre los Novísimos, Oración a Nra. Sra. para cada día, Explicación de la bula de la Santa Cruzada, Modo de ayudar a Misa y Letanía de Nuestra Señora. En el «catecismo menor» sólo incluye La Confesión en romance, Acto de Contrición, la Oración breve y el Modo de ayudar a Misa.

88. El texto citado figura a contiriuación del reproducido en la nota $n .^{\circ} 25$. 
la reacción protestante: presentación sintética del mensaje cristiano, interés por la integridad del mismo así como su pureza doctrinal, afirmación expresa y neta de los puntos discutidos por los protestantes, ausencia de la iluminación bíblica y preponderancia del tono doctrinal en la exposición sin remitir expresamente a las fuentes de la revelación, etc... ${ }^{89}$.

Tales características han estado presentes en los catecismos que con este cariz se escribieron fuera y dentro de nuestras fronteras. Pero en lo que hace a los nuestros, con frecuencia, por no decir siempre, se han aplicado indistintamente al conjunto del texto.

Al carecer de una visión crítica no sólo se han hecho pasar por originales afirmaciones que se han incorporado mucho después, sino que se han enjuiciado todas desde idénticos puntos de vista, siendo así que obedecen a manos distintas, cada una con una intención particular y en un momento histórico diverso. No resulta, pues, honesto simplificar el enjuiciamiento crítico como hasta ahora se ha venido haciendo y en lugar de englobar, habrá que tratar por separado cada una de las intervenciones.

\section{A. Núcleo del P. Gaspar Astete}

Lo primero que habría que decir de lo escrito por el $\mathrm{P}$. Astete es que resulta tributario del sistema catequético imperante en su época tanto en lo que se refiere a la división tradicional de las partes del catecismo, como al método empleado a base de preguntas y respuestas. Ello condiciona toda la presentación incluida en el catecismo, que podría haber sido más expositiva incluso tratándose de niños.

Además, todo el planteamiento de su exposición es fundamentalmente antropocéntrico, en el sentido de que no va a presentar como agente principal de la salvación a Dios que tiene la iniciativa de buscar al hombre, sino por el contrario, desde la situación y las necesidades del hombre, en función de su naturaleza y de su estado busca una respuesta en la exposición de la doctrina católica.

$\mathrm{Su}$ exposición no es completa, en el sentido de que deja muchas lagunas y omisiones. Son muchas las cuestiones no tratadas (lo hará después sobre todo Menéndez de Luarca), quizá porque hace una selección ceñida a lo que estima como fundamental y más necesario, o a lo más adaptado a la capacidad de los niños. Además de esto, en las cuestiones que trata, no se concreta excesiva-

89. Algunas de las características más notables están señaladas por Alfredo García SuÁREZ, Algunas reflexiones sobre el sentido y la evolución histórica de los catecismos en la Iglesia, en «Actualidad Catequética», n. ${ }^{\circ} 76$ (enero-marzo de 1976), p. 159-164. Ver también: Vicente M. ${ }^{a}$ Pedrosa, El catecismo para los preadolescentes «Con vosotros está». Génesis histórica, en «Actualidad Catequética», n. ${ }^{\circ}$ 81-82 (enero-junio 1977), p. 81-112. 
mente en detalles, sino que se limita a exponer los hechos o la doctrina de una manera genérica y sin poner la atención en matizaciones o sutilezas que escapan a un interés inmediato de los niños. Piénsese, por ejemplo en el hecho de limitarse a enunciar la encarnación de Cristo, donde no se entretiene en aclaraciones ulteriores.

En esta misma línea, toda la parte de exposición dogmática del credo va contemplando nada más que lo esencial y no aporta prácticamente ninguna razón que justifique la fe que se expone. Parece que se ciñe a un esquema tan simple como o se acepta o se rechaza. Y si se acepta, la fe del creyente se apoya plácidamente en la fe de la Iglesia y en los doctores que ella tiene, aunque se mantenga una cierta ignorancia.

Tal como se plantea el tema de la oración en la segunda parte del catecismo, apenas deja lugar a la iniciativa personal, sino que inclina a servirse de oraciones ya hechas. Y desde luego no aparece más que como personal; lo comunitario está ausente del texto.

La presentación que hace de los mandamientos también resulta extremadamente sencilla. No profundiza demasiado en los detalles, ni siquiera le preocupa el plantear alguna cuestión que pudiera atañer más directamente a los problemas morales que se pudieran presentar a los niños.

Para los dos primeros mandamientos sigue un procedimiento distinto del usado para los restantes: se ocupa en alguna cuestión más y parece que pone más interés en su cumplimiento. Para varios mandamientos $\left(5 .^{\circ}, 6 .^{\circ}, 7 .^{\circ}, \mathrm{y}\right.$ $8 .^{\circ}$ ), después de repetir su enunciado pregunta: ¿Qué se manda en él? Aunque la pregunta está formulada en un tono positivo, la respuesta es principalmente negativa (no hacer mal, no quitar, no juzgar...).

Para los mandamientos de la Iglesia y las obras de misericordia, se limita a dar genéricamente su razón de ser. En ambos catálogos de mandamientos no entra en detalles sobre la calificación moral o la distinción minuciosa de pecados.

Los sacramentos están vistos desde la funcionalidad de los mismos puestos al servicio del hombre; ¿Para qué es el sacramento de...? Sólo al plantear las cuestiones preliminares de los sacramentos aparece la acción de Dios, que después, en la exposición detallada de cada uno, queda relegada a la penumbra o al olvido. De todos los sacramentos el que más le ocupa es la penitencia, pero ni siquiera en ese caso lo hace con minuciosidad: la mayor parte de las preguntas se dirigen a la diferencia entre pecado mortal y venial y a los actos del penitente.

La impresión global que se deduce del conjunto de lo escrito por Astete viene a confirmar la idea de que se despreocupa de las cuestiones secundarias, y que a pesar de las muchas lagunas observadas, quiere hacer una presentación nuclear de la fe. No se trata de la que recientemente se ha denominado como catequesis kerigmática, por cuanto los planteamientos son diversos. Pe- 
ro la intención de Gaspar Astete es proporcionar un instrumento que instruya en lo fundamental de la fe cristiana sin excesivas complicaciones.

No resulta por otra parte un texto demasiado polémico para reafirmar contra las doctrinas luteranas la pureza de la fe católica. Y aunque se mantiene dentro de ella, el carácter antiprotestante no resulta en él de manera especial.

\section{B. Aportaciones de Gabriel Menéndez de Luarca}

En las numerosas intervenciones de Gabriel Menéndez hay que subrayar inicialmente su desacuerdo profundo con la ignorancia, que no solamente en los niños, sino también en los adultos se halla de la Doctrina Christiana. Es mís, señala que ello proviene, de no estudiarse más que el Catecismo del $P$. Gaspar Astete.

De tan radical planteamiento como manifiesta se deduce inmediatamente la intención que preside todas sus añadiduras. Sobre la base de Astete, como texto comúnmente aceptado, va a tender a perfeccionarlo, sobre todo llenando las omisiones en que Astete incurriera y que son la base de tan difundida ignorancia. Es importante hacer notar que no corrige ni rectifica un sólo punto de la exposición que Astete había hecho. Se limita a añadir, por adición, nuevas precisiones dentro de una respuesta, o, lo que suele ser mucho más frecuente, a añadir muchas más cuestiones para abordar puntos que Astete ni siquiera ha mencionado.

La gran cantidad de añadiduras de Menéndez de Luarca se han mezclado tan íntimamente con el núcleo original, que han llegado a constituir casi una unidad. Ya hemos señalado que son escasas las ediciones que se ocupan de distinguir lo escrito por Gabriel Menéndez. Ello hace que haya marcado un estilo para todo el catecismo tal como sálió de sus manos y que el texto tan simple —quizá excesivamente simple- de Astete resultara mucho más farragoso e intrincado.

Menéndez de Luarca es mucho más sutil. No se conforma fácilmente con plantear una cuestión determinada y quiere profundizar en ella hasta sus últimas consecuencias. Como ejemplos típicos de esto se podría recordar lo que aporta a las cuestiones de la distinción de naturalezas, entendimientos y voluntades que hay en Dios y en Jesucristo hecho hombre, así como todas las cuestiones relativas a la Encarnación y la forma de llevarse a cabo.

Podría decirse que es un perfeccionista que busca no dejar por ningún lado cabos sueltos, lo cual le lleva a ampliar en algunos casos el número de preguntas desbordando con mucho las que escribiera Astete. Pero no sólo en la cantidad se adivina su intención perfeccionista. También en la calidad de las preguntas la sutilidad de las cuestiones planteadas apunta en la misma dirección. A ello hay que añadir el tono y la hondura de las contestaciones, ya que 
en muchos casos su interés por dar una doctrina más segura y completa le lleva a presentar para niños respuestas que son propias de adultos y que ha incluido en su «catecismo mayor».

De ninguna manera se puede olvidar que es un moralista. Su inquietud moralizante se adivina mucho más en los mandamientos y Sacramentos. En la exposición de ambas partes su aportación es decisiva para poder calificar al texto por el retocado como de «epítmo de moral».

En los mandamientos es casi exhaustivo al enumerar las posibles formas de transgresión de cada precepto, algunas a todas luces desproporcionadas a las posibilidades de los niños a quienes pretende dirigirse.

Además, está notablemente inclinado al rigorismo a la hora de otorgar una calificación moral a las faltas cometidas. De las 26 ocasiones en que habla de calificación moral de algún pecado, son 22 las que señala que se incurre en pecado mortal ${ }^{90}$, y tan sólo en cuatro ocasiones habla de pecado venial ${ }^{91}$. Llama especialmente la atención el duro juicio de incurrir en pecado mortal por faltar al ayuno o a la abstinencia, y que en un afán de perfeccionar el texto no admita siquiera en algunos casos la posibilidad de falta leve.

Con idéntico rigor lógico y de juicio, incluye un aspecto de justicia que Astete había omitido: la obligación de restituir los bienes o la honra perdidos como consecuencia de haber faltado a los mandamien os séptimo y octavo.

En torno a los sacramentos; el interés de sus aportaciones prima ordinariamente sobre las disposiciones que ha de tener quien va a recibir cada uno de los sacramentos ${ }^{92}$. No compone un tratado litúrgico moral destinado a los ministros de los sacramentos en orden a la validez de los mismos, sino un compendio de fórmulas para advertir a los receptores de los sacramentos de las condiciones en que les es lícito acceder a ellos.

Particular importancia reviste para un moralista todo lo relativo a la penitencia. Y si Gaspar Astete se había detenido más en ella que en los demás sacramentos, Menéndez de Luarca añade cuestiones sobre cuestiones y preguntas sobre preguntas para dar una minuciosa visión de la penitencia, con todo lujo de detalles ${ }^{93}$.

90. En algunos casos suaviza el juicio: mortal por lo regular, regularmente..., aunque no especifica más.

91. Habla de pecado venial cuando se trata de jurar sin justicia, si de ahí se sigue un mal leve; al jurar sin necesidad sin causa grave o en cosas de escasa importancia; al trabajar en día de fiesta menos de dos horas; y al maldecir sin deseo de mal grave, aunciue precisa que en algunos casos, por escándalo, se puede cometer pecado mortal.

92. No lo hace así respecto al sacramento del orden por estimar que los candidatos al mismo serán suficientemente advertidos.

93. Muchos más detalles en torno a la penitencia ofrece en su «catecismo mayor», donde dedica al tema desde la página 147 a la 164. Resulta anecdótico señalar que el penitente se ha de poner «de rodillas a los pies del Confesor (si es hombre, sin espada, ni gorro, y con el pelo desata- 
En cuanto a la Eucaristía, además de las cuestiones que más interesan a un moralista, amplía el espectro para incluir en una serie de preguntas algunos matices sobre la presencia de Cristo en la Eucaristía y lo relativo a la transubstanciación.

El peso específico de la intervención de Gabriel Menéndez de Luarca en el texto preexistente de Astete imprime a éste un todo y un matiz que está totalmente ausente en la obra primitiva. Puesto que es tanto en cantidad y tan notabie en calidad la aportación de Gabriel Menéndez, podemos saludar como bienvenida la hora de poder marcar la diferencia entre ambos y de atribuir a cada cual el juicio que le corresponde.

\section{Aportaciones de Benito Sanz y Forés}

Al describir con detalle el catecismo, hemos ido dejando constancia de las catorce intervenciones que Sanz y Forés hizo al mismo. Siete en forma de preguntas, que aunque con modificaciones podemos atribuirle, en torno a la cuestión del ayuno y la abstinencia. Esas aportaciones trataban de actualizar la materia a las nuevas disposiciones.

De las siete aportaciones restantes, tres tratan asimismo de actualizar la doctrina del catecismo a las nuevas definiciones de la Inmaculada Concepción y la infalibilidad pontificia. Otras tres pretenden matizar algún concepto poco explícito o incluso omitido también por Menéndez de Luarca. El sentido de un Dios remunerador es una de ellas; otra consiste en advertir del riesgo de dilatar el cumplimiento de un voto o promesa, por el peligro de no poderlo llevar a cabo; la tercera nos habla de lo que hay que hacer antes de comulgar si tras haber confesado recuerda el penitente otro pecado no dicho en la confesión. La última aportación de Sanz y Forés, de escasa entidad es la traducción del Pater noster a su correspondiente castellano.

Existe en todas sus intervenciones un afán perfeccionista para hacer o remodelar el catecismo $\in$ el sentido de que sea completo y nada le falte.

Sin embargo, ello es imposible, pues dado su carácter de resumen las explicaciones prolongadas y la adecuación a casos particulares no tiene cabida en sus páginas.

Prima, a pesar de todo, el interés de que nada falte en él y consciente de las deficiencias que tiene el catecismo por su falta de adecuación a las exigencias de la evolución dogmática, añade su cuño con las aportaciones y actualizaciones ya reseñadas.

do, y si es muger (sic) con la cabeza cubierta». Aún más detalles prescribe para la confesión el catecismo de Pedro de Calatayud (Villagarcía, 1764), en las pp. 74 y 75. 


\section{Aportaciones de Daniel Llorente}

La intervención de Daniel Llorente en el texto ya tan retocado de Astete va en consonancia con toda su línea de actuación en el campo de la catequesis. Siempre le ha preocupado ir perfeccionando los métodos de transmisión del mensaje, pero a la vez ha tenido una inquietud por la pureza en la expresión, tanto doctrinal como lingüística.

Por tanto, la aportanción mayor que él hace, aunque ya había intentos anteriores, consiste en la inclusión del orden cíclico en el estudio del catecismo. Se pretende con él la adaptación pedagógica a la creciente capacidad de los niños según las edades. En consecuencia, la distribución de materia que selecciona para cada ciclo persigue la finalidad de adecuarse a la capacidad concreta de esa edad. El señalar la materia correspondiente a cada uno de los ciclos establecidos dentro de su «Programa Cíclico de instrucción religiosa» primero ${ }^{94} \mathrm{y}$ después de su «Plan cíclico-concéntrico» ${ }^{95}$, va en esta dirección. La forma de hacerlo con mayor sencillez es la de elegir varios tipos de letras de suerte que no se altere el orden completo del catecismo, pero se puede pasar fácilmente a las cuestiones propias de cada ciclo.

En la misma línea de aportación metodológica va también la que hemos señalado varias veces de incorporar la pregunta en la respuesta para que ésta tenga sentido completo por sí misma y facilitar así su comprensión y su consiguiente memorización.

Como tal modificación no se puede armonizar en todos los casos con la readacción previa, se ve obligado a corregirla en muchas ocasiones. A tal corrección redaccional habría que añadir las múltiples correcciones estilísticas casi inadvertidas en el lenguaje propio de los autores que habían intervenido antes de él. A pesar de todo, son correcciones de mínima importancia, puesto que conserva prácticamente en su totalidad la forma de expresarse propia de cada uno. Es más él mismo reconoce que en las modificaciones en que ha intervenido ha procurado aportar un estilo arcaizante:

«Hasta en lo referente al precepto del ayuno y de la Bula procuré conservar el sabor arcaico y el estilo del autor» ${ }^{96}$.

Además de las correcciones estilísticas, fruto de la mano de Daniel Llorente, otra aportación a la que él contribuye es la actualización de la disciplina eclesiástica del ayuno, según su testimonio directo. Dos preguntas son inne-

94. Editado por primera vez en Valladolid en 1913.

95. Publicado por primera vez en «Revista Catequística» 15 (1924), p. 233-238 con el título Plan de instrucción religiosa para catequesis y colegios. Lo incorporó a su Tratado elemental de Pedagogía Catequística desde la primera edición (1928), aunque lo corrigió y perfeccionó husta adquirir su forma definitiva a partir de la quinta edición (1944).

96. Informe de Daniel Llorente de 1942 dirigido al Nuncio Cicognani, titulado Estado actual de la catequesis en Espana. Título VII: Textos de catecismo. Inédito. 
gablemente de él, y otras dos sobre el mismo tema se le pueden atribuir con un margen de error. Además, es posible que a su mano se deban algunas de las modificaciones surgidas en las preguntas de Sanz y Forés sobre el tema, aunque resulta difícil precisarlo por tratarse de unas preguntas que han variado notablemente en su redacción, no ajustándose a un modelo ya hecho como ocurría con las cuestiones heredadas de Astete o de Menéndez de Luarca.

La preocupación de Daniel Llorente en torno a la precisión y exactitud doctrinal, le ha movido también a hacer hasta un total de diez modificaciones (incluyendo la supresión de «pecado mortal» que hacía Gabriel Menéndez para recibir la Unción de enfermos). Por último, habría que consignar en su haber la reducción de dos preguntas originales de Astete a una sola, sin que por ello se vea violentada ni la doctrina contenida, ni su expresión.

Hay en cambio un detalle que habla en contra de la adecuación del catecismo a las nuevas formulaciones de fe, y que no ha quedado recogido en las últimas ediciones hechas por Daniel Llorente a pesar de su interés por la exactitud doctrinal. Nos referimos al hecho de la proclamación, en 1950, del dogma de la Asunción de María al cielo. En las ediciones de Daniel Llorente hechas con posterioridad a tal fecha, no encuentra cabida en el texto una pregunta que haga referencia directa a la declaración dogmática. Se encuentra tan sólo muy discretamente a partir de la edición $21 .^{a}$ de su adaptación (1951), cuando recoge entre las invocaciones de la letanía la de "Regina in coelum assumpta» ${ }^{97}$. Considera suficiente el que al hablar de la Virgen el P. Astete dijera que «es Madre de Dios, y está en el cielo» ${ }^{98}$.

Con la valoración crítica que acabamos de hacer, el catecismo ha ido pasando desde un núcleo relativamente simple escrito por el $P$. Astete, a imbuirse de un espíritu moralizante que penetra notablemente en todas sus páginas por obra de Gabriel Menéndez. De ahí pasamos a la actualización dogmática y la exquisita minuciosidad de conceptos iniciada por Sanz y Forés y completada por Daniel Llorente. Además a éste último debemos el perfeccionamiento metodológico de un texto aceptado e impuesto por la tradición.

Queda, pues, claro que lo que ha llegado a nuestras manos es el resultado de una labor de arrastre a ta que se han ido sumando, con indudable buena intención, pero con poco sentido crítico, las innovaciones posteriores. Hay algu-

97. Tampoco se incorpora de una manera expresa en el texto el dogma de la Asunción en la edición de Logrono de 1950, aunque termina las "advertencias preliminares» aludiendo en la fecha a «la proclamación del dogma de la Asunción de la Santísima Virgen en cuerpo y alma a los Cielos».

En la edición de Arturo Alonso (Salamanca, 1977) queda recogido en la página 23.

98. En su «catecismo mayor», Menéndez de Luarca habla expresamente del tema: ¿ Y.cómo está en el Cielo? -Gloriosa en Cuerpo y alma. ¿Pues no murió? -Sí murió; pero al tercero día (?) después de su muerte, el Señor la resucitó, y en Cuerpo, y Alma subió gloriosa a los Cielos, donde está a la diestra de su Hijo, y sobre todos los Coros de los Ángeles» (l.c., p. 64). 
na otra adición más debida a alguna mano que aún permanece en el anonimato, pero que desde luego carece de importancia en el conjunto del texto.

\section{CONSIDERACIONES SOBRE EL LENGUAJE EMPLEADO}

No sería lícito terminar el presente estudio sin hacer una parada, aunque sea muy somera, en torno a la cuestión de la termirología y lenguaje usado por cada uno de los que han intervenido eficazmente en la configuración del texto. Las diferencias en el tiempo son las primeras que vienen a la mente a la hora de contemplar con una cierta distancia las expresiones que han ido usando respectivamente.

No es lo mismo escribir casi finalizado el siglo xvı, que en el último tercio del XVIII, o un siglo después como hace Sanz y Forés, o ya muy recientemente, aunque hayan transcurrido más de sesenta años desde la primera edición de Daniel Llorente. Cada uno de ellos obedece a los imperativos estilísticos de una época. Y las palabras y expresiones que entonces eran usuales hoy no tienen vigencia en todos los casos. Aun concediendo que en cada una de las adaptaciones sucesivas el texto refundido fuera inteligible para el público infantil al que se destinaba, hoy resulta muy difícil, por no decir imposible, hacer que un niño entienda de una manera directa expresiones que han perdido actualidad. Y cuanto más distantes en el tiempo, más abundan las expresiones, palabras y giros inasequibles a lo niños de hoy.

Nos hemos permitido espigar algunas de tales palabras o frases difíciles. $\mathrm{Al}$ extraerlas de su contexto inmediato (aunque no totalmente) puede ser una dificultad para su captación; pero tiene por contraposición una ventaja: la de llegar a la conclusión de estar presentado la doctrina cristiana bajo un ropaje totalmente anticuado. El presentar todas ellas en conjunto refuerza sin género de duda la impresión apuntada.

\section{A. Expresiones originales de Gaspar Astete}

Comienza diciendo que "Todo fiel cristiano es muy obligado» (posteriormente substituida por "está muy obligado»). Én los mismos versos iniciales encontramos: «quiso morir por nos redimir» (parecida expresión después retocada en el Padrenuestro: «Venga a nos...). ¿De qué nos tiene que redimir Cristo?: «De,nuestro pecado y del enemigo malo». Dudosa expresión para designar al demonio. Quizá obligada por las exigencias de la versificación. En los mismos versos iniciales, y después hablando de la señal de la cruz, se dice que la tercera cruz ha de hacerse «en los pechos» ${ }^{99}$.

99. Ver la nota 42 donde hacemos alusion a esta expresión. 
La fórmula del Padrenuestro presenta signos de una versión secular del texto latino. Se habla de «santificado sea el tu nombre; venga a nos el tu reino». Recientemente se han modificado. Pero no así los conceptos emparentados entre sí y que aún hoy subsisten al hablar de «deudas» y «deudores» en la petición de perdón ${ }^{100}$. En el Ave María, cabe destacar: «El Señor es contigo».

En los artículos de la fe, que se refieren a la humanidad de Cristo, el tercero habla de que murió "por salvar a nosotros pecadores»; y el séptimo hablando de Cristo que vendrá como juez, además de usar el signo ortográfico de los dos puntos, dice: "conviene a saber, a los buenos...".

La Declaración de la Doctrina Cristiana comienza con el sistema de preguntas y respuestas. Pero resulta extraño, al menos para el uso actual dirigirse a un niño con el término desusado de «vos»: ¿Sois cristiano? (Más adelante lo dirá expresamente como cuando pregunta: ¿Vistéis vos nacer a Jesucristo?). Después pregunta por el origen del nombre cristiano: « ¿Ese nombre de cristiáno de quién le hubisteis?». También del cristiano precisa que es quien «está ofrecido a su santo servicio». Volviendo sobre la señal de la cruz pregunta: «¿Cuándo habéis de usar esta señal?» y «¿De dónde tiene la Cruz esta virtud?».

En la primera parte, en la explicación del credo, dice que lo hicieron los apóstoles «para informarnos en la santa fe». Más adelante hace una pregunta en la forma entonces usual: «¿Creéislo?», en lugar de la actual «¿Lo creéis?», 0 «¿lo crees?».

La pregunta global sobre la fe cristiana está formulada así: «¿Qué cosas son las que tenéis y creeis como cristiano?». Los artículos de la fe, expresión paralela del credo son «para dar noticia distinta de Dios...». Del mismo Dios dice que «es una cosa la más excelente y admirable que se puede decir ni pensar» ${ }^{101}$. De Dios pregunta también si «tiene figura corporal como nosotros». $\mathrm{Al}$ hablar de la Encarnación pregunta quién de las tres divinas personas se kizo hombre, pero la expresión usada es: «¿El Padre hízose hombrie?». Jesús resucita «tornando a juntar su cuerpo y alma gloriosa». La Iglesia es «la congregación de los fièles cristianos...». La reflexión con que termina la primera parte nos recuerda que a los doctores de la Iglesia les corresponde «dar cuenta por extensoin de la fe; en cambio, al niño destinatario del catecismo, «bástaos darla de los Artículos como se contienen en el Credo».

100. La actual versión usada en Hispanoamérica ha corregido las locuciones anticuadas del Padrenuestro. Las fórmulas francesa, inglesa y alemana son más expresivas que la que usamos en España.

101. La expresión cosa designando a Dios no es despectiva. Es usada por Astete frecuentemente con un carácter genérico: «¿Qué cosa es Fe?», por ejemplo. También Ripalda la usa como en «¿Qué cosa es vida perdurable?». 
La segunda parte de la doctrina cristiana dedicada a la oración afirma que ésta consiste en «levantar el corazón a Dios y pedirle mercedes». El Padrenuestro «le dijo Cristo por su boca» y tienen «siete peticiones fundadas en toda caridad». En la segunda petición imploramos «que reine Dios en nuestras almas acá en la tierra por gracia...»; en la cuarta petición solicitamos de Dios «el mantenimiento conveniente para el cuerpo, el espiritual de la gracia...». Pasando a la Salve, nos dice que la «Iglesia la tiene recibida». Los ángeles y los santos interceden ante Dios como «nuestros medianeros».

En los mandamientos que constituyen la parte tercera, el cumplimiento del primero de ellos consiste en amar a Dios sobre todas las cosas hasta el punto de estar dispuesta a «antes perderlas todas que ofenderle», en lugar del actual «perderlas todas antes que ofenderle»; contra este mandamiento peca quien cree en «agüeros». El cuarto mandamiento manda honrar a los padres y a otros que «son entendidos por padres». El quinto mandamiento prohíbe hacer mal a otro «en hecho..., en dicho, (y).... por deseo». Quebranta el octavo mandamiento «el que contra razón juzga...». El segundo mandamiento de la Iglesia obliga a «confesar a lo menos una vez en el año, o antes si espera haber peligro de muerte...»; el tercero manda «comulgar por pascua florida». La segunda obra de misericordia de las espirituales recomienda «dar buen consejo al que lo ha menester».

Pasamos a la cuarta parte que versa sobre los sacramentos. Los cinco primeros «son de necesidad, de hecho, o de voluntad»; los dos últimos «son de voluntad». La virtud de la caridad nos obliga a portarnos bien con nuestros prójimos, «habiéndonos con ellos como quisiéramos que ellos se hubiesen con nosotros». Las tres partes de la penitencia que señala Astete o los tres actos del penitente están indicadas con dos substantivos unidos con la preposición «de», y que resultan difícilmente comprensibles para la mentalidad infantil actual: "contrición de corazón, confesión de boca y satisfacción de obra». Acerca de la obligación de confesar inmediatamente los pecados mortales cometidos dice que «Bien sería, pero no es necesario». La unción de enfermos sirve entre otras cosas «para quitar los rastros y reliquias de la mala vida pasada»; además, «para dar esfuerzo al alma...». El matrimonio sirve «para casar y dar gracia a los casados».

Los pecados capitales son definidos como «apetitos desordenados»; en particular, la avaricia es un "apetito desordenado de deseo de hacienda», y la lujuria, «de sucios y carnales deleites». Al señalar los medios para vencer al demonio, uno de los enemigos del alma, se recomiendan las «asperezas, disciplinas y ayunos...»; del mundo se huye, en cambio, despreciando «sus pompas y vanidades». La segunda de las bienaventuranzas nos recuerda que los mansos son los que no tienen ira "ni aun casi movimiento de ella». Y los que "han hambre y sed de justicia» son «los que hacen con ansia el deber en todo»; los «pacíficos» son "los obradores de la paz».

El elenco recorrido en las expresiones de Astete resulta elocuente. Algu- 
nas, muy pocas, de tales expresiones han sido después modificadas por Daniel Llorente, pero la mayor parte han pasado literalmente a todas las ediciones, incluidas las más recientes.

\section{B. Expresiones originales de Gabriel Menéndez}

Aunque el lenguaje de Astete es el propio del siglo xvi, también en las frases introducidas en el siglo xviI por Gabriel Menéndez necesitan en algunos casos una explicación y al menos en una primera lectura llaman la atención; especialmente si se piensa que han de ser entendidas por los niños. Son menos en número debido sin duda a que la evolución del idioma las hace en general más próximas a las que empleamos en la actualidad. Veámoslas.

Para definir la oración mental nos dice que «es la que se hace exercitando las potencias del Alma». Jurar sin necesidad consiste en «jurar sin causa grave, o por cosa de poco momento». Faltan contra el cuarto mandamiento los hijos que a sus padres «les levantan la mano». También los padres tienen obligaciones para con sus hijos y cuando faltan a ellas pecan «regularmente mortalmente». Extraña combinación de dos adverbios de modo, corregida luego por Daniel Llorente.

Pueden pecar mortalmente por maldecir los que tienen costumbre de hacerlo «y no hacen diligencias para arrancarla». Hablando de las gracias actuales nos especifica que sin ellas no «podemos principiar, ni continuar, ni concluir cosa conducente para la vida eterna». Las dos expresiones anteriores la encontramos unidas con ocasión del examen de conciencia que consiste en «hacer las diligencias conducentes para acordarse uno de los pecados...». La terminología de la filosofía escolástica también encuentra un hueco, pues tras la consagración quedan «los accidentes de pan y vino».

El demonio, enemigo del alma, es un «ángel... revelado (sic) contra $S u$ Magestad (sic)...» forma entonces usual de hablar de Dios ${ }^{102}$. Sobre el alma humana pregunta «Y ¿qué cosa es nuestra Alma, cuyas son estas potencias?». En la recomendación final escrita por Gabriel Menéndez se aconsejan varios medios piadosos útiles para el cristiano, «y por decir uno que abraza muchos», recomienda la elección de un buen confesor.

Habría que añadir las de «examen de conciencia» y «propósito de la enmienda», como actos previos a la confesión.

También algunas de las expresiones de Menéndez de Luarca han sido retocadas por Daniel Llorente, pero la totalidad de las que hemos espigado se han incorporado a las más recientes ediciones de los catecismos.

102. Ver en la p. 13 el prólogo reproducido donde también se refiere a Dios como «Su Ma gestad». 
Las adiciones de Sanz y Forés y de Llorente suelen ser en general más inteligibles y adolecen en menor cuantía del defecto de ser desusadas o de resultar totalmente imposibles de entender por los niños ${ }^{103}$.

La lectura continua de las expresiones entresacadas obliga a preguntarse si resultan asequibles a la mentalidad infantil. Abrigamos serias dudas al respecto. Y aunque en los más recientes catecismos publicados en nuestra nación no se haya conseguido plenamente encontrar la formulación exacta que respetando la doctrina se aproxime a la inteligencia de los niños, creemos que se han dado bastantes pasos en la buena dirección.

No se trata solamente de una aproximación lingüística; hay cuestiones más profundas que obligan a poner en tela de juicio la recomendación del uso del catecismo denominado de Astete para la formación religiosa de los niños de hoy. Algunas de las cuestiones han quedado apuntadas en el presente trabajo.

La sencilla visión teológica original de Astete no es suficiente para hoy. Mucho menos cargando a sus espaldas con el acentuado cuño moralista impreso por Gabriel Menéndez. Ni siquiera las últimas actualizaciones de Sanz y Forés y de Daniel Llorente salvan la distancia que media entre un texto del xvi y la mentalidad y necesidades actuales.

103. Para Sanz y Forés, Dios es premiador de buenos y castigador de malos. El papa es infalible «en las cosas tocantes a la fe». Daniel Llorente ha conservado el sabor arcaico de ediciones anteriores, pues al indicar los privilegios de la Bula incluye el de poder tomar «lacticinios, huevos y pescado en la colación y desayuno". 